\title{
Characterization of $\mathrm{Co}^{2+}$ - and $\mathrm{Fe}^{3+}$-Codoped $\mathrm{TiO}_{2}$ Nanomaterials for Photocatalytic Degradation of Organic Pollutants under Visible Light Irradiation
}

\author{
Nguyen Thi Tuyet Mai, ${ }^{1}$ Nguyen Kim Nga ${ }^{D},{ }^{1}$ Dang Thi Minh Hue, ${ }^{1}$ Ta Ngoc Dung, \\ Huynh Dang Chinh, ${ }^{1}$ and Tran Quang Huy $\mathbb{1}^{2}$ \\ ${ }^{1}$ School of Chemical Engineering, Hanoi University of Science and Technology, 1 Dai Co Viet Road, Hanoi, Vietnam \\ ${ }^{2}$ Phenikaa University Nano Institute (PHENA), Phenikaa University, Hanoi 12116, Vietnam \\ Correspondence should be addressed to Nguyen Kim Nga; nga.nguyenkim@hust.edu.vn
}

Received 1 August 2021; Revised 4 October 2021; Accepted 11 October 2021; Published 18 November 2021

Academic Editor: Tien Duc Pham

Copyright (C) 2021 Nguyen Thi Tuyet Mai et al. This is an open access article distributed under the Creative Commons Attribution License, which permits unrestricted use, distribution, and reproduction in any medium, provided the original work is properly cited.

\begin{abstract}
In this study, $\mathrm{TiO}_{2}$ nanomaterials were prepared using a solvothermal method and codoped with $\mathrm{Co}^{2+}$ and $\mathrm{Fe}^{3+}$ ions for the photocatalytic degradation of organic pollutants under visible light. The physicochemical properties of the obtained materials were studied by powder X-ray diffraction, field emission electron scanning microscopy, energy-dispersive X-ray spectroscopy, and nitrogen adsorption isotherms. Optical absorption was characterized by UV-vis absorption spectroscopy. The photocatalytic activities of the prepared materials were evaluated through methylene blue (MB) degradation under visible light irradiation. Results showed the excellent performance of $\mathrm{MB}$ degradation investigated on $\mathrm{TiO}_{2}$ samples codoped with $\mathrm{Co}^{2+}$ and $\mathrm{Fe}^{3+}$ in comparison with undoped and $\mathrm{Co}^{2+}$-doped $\mathrm{TiO}_{2}$ samples. The codoped $\mathrm{TiO}_{2}$ samples degraded $85 \%-90 \%$ of $\mathrm{MB}$ after $120 \mathrm{~min}$, whereas all the prepared $\mathrm{TiO}_{2}$ samples were composed of pure anatase phase and had a spherical-like shape and mean crystalline size ranging from $6.2 \mathrm{~nm}$ to 7.8 determined by Scherrer's equation. The optical absorption of the $\mathrm{TiO}_{2}$ codoped with $\mathrm{Co}^{2+}$ and $\mathrm{Fe}^{3+}$ was significantly enhanced toward the visible light region. The pseudo-second-order kinetic model fits well for the degradation of $\mathrm{MB}$ on as-prepared $\mathrm{TiO}_{2}$ codoped with $\mathrm{Co}^{2+}$ and $\mathrm{Fe}^{3+}$.
\end{abstract}

\section{Introduction}

The development of metal oxide nanoparticles has been extensively attracted as adsorbents and photocatalysts for the treatment of dye-containing wastewater [1-3]. Titanium dioxide $\left(\mathrm{TiO}_{2}\right)$ nanoparticles have considerable attention because of their long-term stability, low cost, and nontoxicity [4]. However, the major drawback of $\mathrm{TiO}_{2}$ is a large bandgap energy $(\sim 3.2 \mathrm{eV}$ and $3.0 \mathrm{eV}$ for anatase and rutile phases, respectively), and it requires ultraviolet (UV) irradiation (wavelength, $\lambda<387 \mathrm{~nm}$ ) for activation. Many attempts have been conducted to extend the photocatalytic activity of $\mathrm{TiO}_{2}$ from a UV to visible light region (wavelength, $\lambda: 400-700 \mathrm{~nm}$ ). Doping of $\mathrm{TiO}_{2}$ with transition metals or nonmetals is the most promising approach used to activate it due to the bandgap energy reduction [5]. Tran- sition metals can provide additional energy levels within the bandgap of a $\mathrm{TiO}_{2}$ photocatalyst. Electron transfer from one of these levels to the conduction band requires lower photon energy than those of undoped $\mathrm{TiO}_{2}$ [6]. Various transition metal ions have been studied to dope with $\mathrm{TiO}_{2}$, including Co [7], Fe [8], Cr [9], Ni [10], and V [11], etc. Furthermore, many researchers have also focused on codoping of $\mathrm{TiO}_{2}$ with two or more metal ions for enhancement of photocatalytic degradation of organic pollutants under solar light irradiation such as $\mathrm{Mn}$ and $\mathrm{Co}$ [12]; $\mathrm{Ni}$ and $\mathrm{Cr}$ [13]; Fe, Co, and $\mathrm{S}$ [14]; and $\mathrm{Fe}$ and $\mathrm{Pr}$ [15]. It indicated that codoped $\mathrm{TiO}_{2}$ could expand its light absorption range toward visible light and thus enhance its photocatalytic efficiency, which is higher than that of single-doped $\mathrm{TiO}_{2}$. It was reported that $\mathrm{Mn}^{2+}$ - and $\mathrm{Co}^{2+}$-codoped $\mathrm{TiO}_{2}$ could degrade about $97 \%$ of enoxacin, which was higher than that of $\mathrm{Co}^{2+}$ single- 
doped $\mathrm{TiO}_{2}$ (degradation percentage $\sim 48 \%$ ) after 80 min of exposure to solar light [12]. A recent work also demonstrated that $\mathrm{Ni} / \mathrm{Cr}$-codoped $\mathrm{TiO}_{2}$ exhibited a higher efficiency of $95.6 \%$ for $\mathrm{MB}$ degradation after $90 \mathrm{~min}$ under sunlight, compared to Ni-doped $\mathrm{TiO}_{2}$ (Ni-doped $\mathrm{TiO}_{2}$ degraded $28 \%-59 \%$ of $\mathrm{MB}$ depending on the amount of Ni doping) [13]. The photocatalytic degradation of Acid Orange 7 azo dye under visible light using $\mathrm{Fe}^{3+}$ - and $\mathrm{Pr}^{3+}$ codoped $\mathrm{TiO}_{2}$ was much more enhanced compared to undoped $\mathrm{TiO}_{2}$ and $\mathrm{Fe}^{3+}$ single-doped $\mathrm{TiO}_{2}$ [15]. Those studies indicated that the photocatalytic activity of doped $\mathrm{TiO}_{2}$ material is greatly dependent on the nature of the dopant ions and their doping concentration and preparation, in which optimal conditions for the synthesis decide the ability of nanomaterials applied for the photodegradation of organic pollutants in wastewater. $\mathrm{Fe}^{3+}$ has been considered the best dopant among the transition metals used for increasing the photocatalytic activity of $\mathrm{TiO}_{2}$ thanks to its similar radius to $\mathrm{Ti}^{4+}(0.63 \AA$ and $0.60 \AA$, respectively). $\mathrm{TiO}_{2}$ doping with $\mathrm{Co}^{2+}$ showed excellent degradation activity of dye molecules; however, the optimal concentration of $\mathrm{Co}^{2+}$ is needed to enhance activity, because the high percentage of $\mathrm{Co}^{2+}$ leads to a reduction in the photocatalytic activity [14].

In this study, we aimed to synthesize and characterize $\mathrm{TiO}_{2}$ nanoparticles codoped with $\mathrm{Co}^{2+}$ and $\mathrm{Fe}^{3+}$ ions using the solvothermal method. The effect of the doping concentration of $\mathrm{Co}^{2+}$ was investigated to determine the optimal condition for preparing a photocatalyst with high activity in the visible light region. The obtained nanomaterials were investigated by various physicochemical methods, including $\mathrm{XRD}$, FE-SEM, EDXS, nitrogen adsorption-desorption isotherms, and UV-vis absorption. Photocatalytic activities of prepared nanomaterials were evaluated for degradation of methylene blue $(\mathrm{MB})$. Our results indicated that the prepared $\mathrm{TiO}_{2}$ materials codoped with $\mathrm{Co}^{2+}$ and $\mathrm{Fe}^{3+}$ showed a highly photocatalytic efficiency compared to single-doped $\mathrm{TiO}_{2}$. This nanomaterial could be an effective alternative for the treatment of wastewater in the textile industry.

\section{Materials and Methods}

2.1. Chemicals and Preparation. All chemicals were of analytical grade and used as received without further purification. Tetraisopropyl orthotitanate $\left(\mathrm{Ti}\left(i-\mathrm{OC}_{3} \mathrm{H}_{7}\right)_{4}\right)$, acetylacetone $\left(\mathrm{C}_{5} \mathrm{H}_{8} \mathrm{O}_{2}\right)$, ethanol $\left(\mathrm{C}_{2} \mathrm{H}_{5} \mathrm{OH}\right)$, and methylene blue $\mathrm{C}_{16} \mathrm{H}_{18} \mathrm{ClN}_{3} \mathrm{~S}$ (MB) were obtained from Merck. Cobalt (II) acetate tetrahydrate $\left(\left(\mathrm{CH}_{3} \mathrm{COO}\right)_{2} \mathrm{Co} \cdot 4 \mathrm{H}_{2} \mathrm{O}\right)$ and iron (III) nitrate nonahydrate $\left(\mathrm{Fe}\left(\mathrm{NO}_{3}\right)_{3} \cdot 9 \mathrm{H}_{2} \mathrm{O}\right)$ were purchased from China. Double-distilled water was used for preparing all solutions.

Single doping of $\mathrm{TiO}_{2}$ with $\mathrm{Co}^{2+}$ and codoping with $\mathrm{Co}^{2+}$ and $\mathrm{Fe}^{3+}$ were conducted by the solvothermal synthesis. The obtained samples were referred to as $\mathrm{TiO}_{2}-x \% \mathrm{Co}-y$ $\% \mathrm{Fe}$, with $x$ and $y$ showing the molar $\mathrm{Co} / \mathrm{Ti}$ and $\mathrm{Fe} / \mathrm{Ti}$ ratio in the starting materials, respectively. In a typical experiment, a mixture consisting of $14.5 \mathrm{~mL}$ of $\mathrm{C}_{2} \mathrm{H}_{5} \mathrm{OH}$ and $0.5 \mathrm{~mL}$ of $\mathrm{C}_{5} \mathrm{H}_{8} \mathrm{O}_{2}$ was stirred for $15 \mathrm{~min}$. The mixture was slowly added with $2.96 \mathrm{~mL}$ of $\mathrm{Ti}\left(i-\mathrm{OC}_{3} \mathrm{H}_{7}\right)_{4}$ as a precursor and stirred for another $30 \mathrm{~min}$ (mixture 1). Desired amounts of $\left(\mathrm{CH}_{3} \mathrm{COO}\right)_{2} \mathrm{Co} \cdot 4 \mathrm{H}_{2} \mathrm{O}$ and $\mathrm{Fe}\left(\mathrm{NO}_{3}\right)_{3} \cdot 9 \mathrm{H}_{2} \mathrm{O}$ were dissolved in another mixture consisting of $5 \mathrm{~mL}$ of $\mathrm{C}_{2} \mathrm{H}_{5} \mathrm{OH}, 1 \mathrm{~mL}$ of $\mathrm{C}_{5} \mathrm{H}_{8} \mathrm{O}_{2}$, and $0.18 \mathrm{~mL}$ of $\mathrm{H}_{2} \mathrm{O}$ for $30 \mathrm{~min}$. The mixed solution was then dropped into mixture 1 with continuous stirring for $30 \mathrm{~min}$ and then transferred to a $100 \mathrm{~mL}$ Teflonlined stainless-steel autoclave maintained at $180^{\circ} \mathrm{C}$ for $12 \mathrm{~h}$. The product was washed several times with double-distilled water until $\mathrm{pH} 7$, dried at $100^{\circ} \mathrm{C}$ for $24 \mathrm{~h}$, and ground on agate mortar. Single-doped and codoped $\mathrm{TiO}_{2}$ samples were designated as $\mathrm{TiO}_{2}-1 \% \mathrm{Co}, \mathrm{TiO}_{2}-2.5 \% \mathrm{Co}, \mathrm{TiO}_{2}-5 \% \mathrm{Co}, \mathrm{TiO}_{2}-$ $1 \% \mathrm{Co}-2.5 \% \mathrm{Fe}$, and $\mathrm{TiO}_{2}-2.5 \% \mathrm{Co}-2.5 \% \mathrm{Fe}$. $\mathrm{TiO}_{2}$ nanoparticles were also prepared as a control and denoted as undoped $\mathrm{TiO}_{2}$.

2.2. Material Characterization. X-ray diffraction (XRD) patterns of the prepared $\mathrm{TiO}_{2}$ samples were recorded with a D8 ADVANCE Bruker Diffractometer within $2 \theta$ range of $20^{\circ}-$ $80^{\circ}$ with a scan step of $0.03^{\circ} \cdot \mathrm{s}^{-1}$ under $\mathrm{Cu}-\mathrm{K} \alpha$ radiation $(\lambda=0.1 .54056 \mathrm{~nm})$. The surface morphology of the $\mathrm{TiO}_{2}$ samples and representative doped $\mathrm{TiO}_{2}$ samples was observed by field emission scanning electron microscopy (FE-SEM, Hitachi S-4800, Japan). The average nanoparticle sizes were calculated from the scanning electron microscopic (SEM) images by using ImageJ software. The elemental composition of the samples was analyzed through energydispersive X-ray spectroscopy (EDXS, Nova NanoSEM 450, FEI). The nitrogen adsorption-desorption isotherms of the representative $\mathrm{TiO}_{2}$ samples were measured at $-196^{\circ} \mathrm{C}$ with a Micromeritics ASAP 2020 apparatus. The total surface areas of the samples were determined by the BrunauerEmmett-Teller (BET) method, and the pore size distribution was determined through the Barrett-Joyner-Halenda (BJH) method using desorption curves. UV-vis absorption spectra were recorded on the Jasco V-670 spectrometer.

The photocatalytic activity of the prepared $\mathrm{TiO}_{2}$ samples was evaluated by degradation of $\mathrm{MB}$ under visible light irradiation. A $250 \mathrm{~W}$ Osram mercury lamp equipped with a UV cut-off filter was used as a visible light source. In a typical experiment, $40 \mathrm{mg}$ of the prepared $\mathrm{TiO}_{2}$ sample was added into a $100 \mathrm{~mL}$ quartz photoreactor containing $50 \mathrm{~mL}$ of $14 \mathrm{mg} \cdot \mathrm{L}^{-1} \mathrm{MB}$ solution. The reaction mixture was then stirred in the dark at a constant speed of $150 \mathrm{rpm}$ for $30 \mathrm{~min}$ to reach the adsorption-desorption equilibrium. The resulting mixture was irradiated under the visible light source for up to $120 \mathrm{~min}$. After predefined intervals (30, 60, 90, and $120 \mathrm{~min}$ ), the samples were removed from the photoreactor and centrifuged. The residual concentration in the supernatant was measured with a UV-vis spectrometer (Agilent 8453, USA) at a wavelength of $665 \mathrm{~nm}$. MB concentration was determined using a linear regression equation obtained by plotting a calibration curve of $\mathrm{MB}$ within a range of known concentrations. The photocatalytic ability of the $\mathrm{TiO}_{2}$ samples was evaluated through the percentage of $\mathrm{MB}$ degradation as follows:

$$
\text { Degradation percent }=\frac{C_{\mathrm{o}}-C}{C_{\mathrm{o}}} \cdot 100 \% \text {, }
$$


where $C_{\mathrm{o}}$ is the initial concentration of $\mathrm{MB}$ and $C$ is the remaining concentration of $\mathrm{MB}$ at a specific time of measurement.

\section{Results and Discussion}

3.1. Characterization of the Synthesized Materials. The XRD patterns of the synthesized samples (undoped, single-doped, and codoped $\mathrm{TiO}_{2}$ ) are shown in Figure 1. The results demonstrated the formation of monocrystalline $\mathrm{TiO}_{2}$ in the anatase phase in all samples. The XRD pattern of undoped $\mathrm{TiO}_{2}$ samples (Figure 1(a)) shows typically crystalline peaks at 2 $\theta=25.1^{\circ}, 37.67^{\circ}, 47.71^{\circ}$, and $54.11^{\circ}$ corresponding to crystal planes (101), (111), (200), and (211), respectively, which can be indexed to the anatase phase of $\mathrm{TiO}_{2}$ (JCPDS card no. 211272). For single-doped and codoped $\mathrm{TiO}_{2}$ samples, those diffraction peaks are observed at $2 \theta=25.22^{\circ}, 25.25^{\circ}, 25.30^{\circ}$, $25.34^{\circ}$, and $25.37^{\circ} ; 37.85^{\circ}, 37.90^{\circ}, 38^{\circ}, 38.09^{\circ}$, and $38.12^{\circ}$; $47.82^{\circ}, 47.88^{\circ}, 47.92^{\circ}, 47.99^{\circ}$, and $48.11^{\circ}$; and $54.35^{\circ}, 54.41^{\circ}$, $54.44^{\circ}, 54.46^{\circ}$, and $54.51^{\circ}$ (see Figures $1(\mathrm{~b})-1(\mathrm{f})$ ) for $\mathrm{TiO}_{2}$ $1 \% \mathrm{Co}, \mathrm{TiO}_{2}-2.5 \% \mathrm{Co}, \mathrm{TiO}_{2}-5 \% \mathrm{Co}, \mathrm{TiO}_{2}-1 \% \mathrm{Co}-2.5 \% \mathrm{Fe}$, and $\mathrm{TiO}_{2}-2.5 \% \mathrm{Co}-2.5 \% \mathrm{Fe}$, respectively. The data indicated that the typical peaks of the anatase $\mathrm{TiO}_{2}$ in single-doped and codoped $\mathrm{TiO}_{2}$ samples were slightly shifted to higher values than those of undoped $\mathrm{TiO}_{2}$ samples. The codoped $\mathrm{TiO}_{2}$ samples (Figures 1(e) and 1(f)) exhibited a decrease in peak intensity and slight broadening of the peaks compared with those of undoped $\mathrm{TiO}_{2}$ and single-doped $\mathrm{TiO}_{2}$ samples (Figures 1(a)-1(d)). Moreover, no characteristic peaks attributed to cobalt and iron compounds were detected in the XRD patterns, which can be attributed to the very low dopant amount in the samples. The observations suggested that $\mathrm{Co}^{2+}$ and $\mathrm{Fe}^{3+}$ cations were successfully introduced into the lattice of $\mathrm{TiO}_{2}$. The average particle sizes of the samples were calculated from the full width at half maximum (FWHM) of the (101) diffraction peak according to the Debye-Scherrer equation [16]:

$$
D=\frac{0.9 \lambda}{\beta \cos \theta}
$$

where $\lambda$ is the $\mathrm{X}$-ray wavelength $(0.15406 \mathrm{~nm}), \beta$ is the line width at half maxima of peaks, and $\theta$ represents the Bragg angle of X-ray diffraction. The obtained results (Table 1) showed that the average particle sizes of all samples were at a nanosized scale ranging from $6.2 \mathrm{~nm}$ to $7.8 \mathrm{~nm}$. The single-doped and codoped $\mathrm{TiO}_{2}$ samples had a smaller size than the undoped $\mathrm{TiO}_{2}$ samples. The undoped $\mathrm{TiO}_{2}$ samples had the largest mean particle size of $7.8 \mathrm{~nm}$. Among the three Co-doped $\mathrm{TiO}_{2}$ samples, $\mathrm{TiO}_{2}-1 \% \mathrm{Co}$ samples had the smallest particle size with a mean particle size of $6.8 \mathrm{~nm}$. The average particle size of Co-doped $\mathrm{TiO}_{2}$ samples increased from $6.8 \mathrm{~nm}$ to $7.5 \mathrm{~nm}$ with an increasing $\mathrm{Co} / \mathrm{Ti}$ molar ratio from $1 \%$ to $5 \%$ in the samples. The high doping amount of Co resulted in an increase in the particle size, which was attributed to the larger radius of $\mathrm{Co}^{2+}(0.74 \AA)$ than that of $\mathrm{Ti}^{4+}(0.60 \AA)$. Therefore, the $\mathrm{Co} / \mathrm{Ti}$ molar ratio of $1 \%$ was considered to be optimal. This ratio was further used to prepare $\mathrm{TiO}_{2}$ codoped with $\mathrm{Co}$ and $\mathrm{Fe}$ with varying

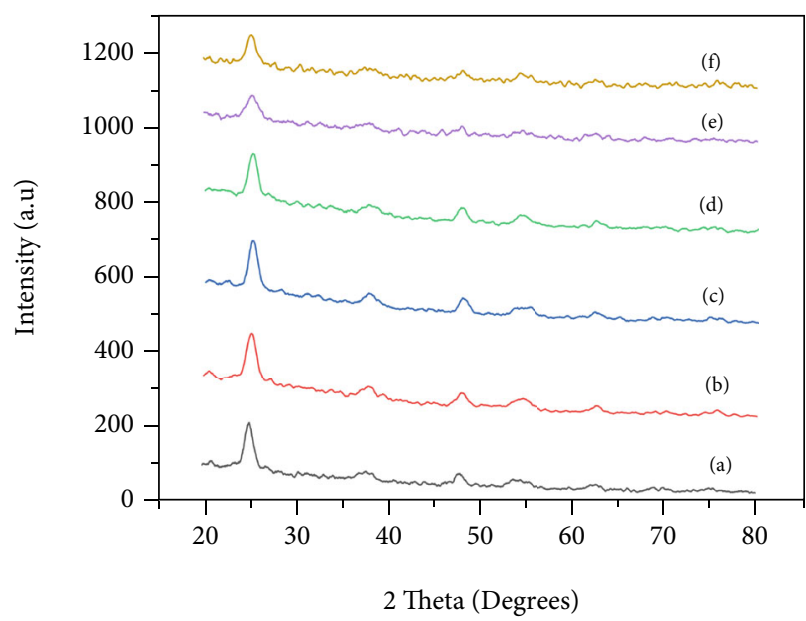

FIgURE 1: XRD patterns of (a) undoped $\mathrm{TiO}_{2}$, (b) $\mathrm{TiO}_{2}-1 \% \mathrm{Co}$, (c) $\mathrm{TiO}_{2}-2.5 \% \mathrm{Co}$, (d) $\mathrm{TiO}_{2}-5 \% \mathrm{Co}$, and co-doped $\mathrm{TiO}_{2}$ : (e) $\mathrm{TiO}_{2}-$ $1 \% \mathrm{Co}-2.5 \% \mathrm{Fe}$ and (f) $\mathrm{TiO}_{2}-2.5 \% \mathrm{Co}-2.5 \% \mathrm{Fe}$.

$\mathrm{Co} / \mathrm{Ti}$ molar ratios from $1 \%$ to $2.5 \%$ and a fixed $\mathrm{Fe} / \mathrm{Ti}$ molar ratio of $2.5 \%$. Previous studies $[14,15]$ reported that the Fedoped $\mathrm{TiO}_{2}$ can extend more excellent absorption in the longer wavelength range than $\mathrm{TiO}_{2}$. As a result, we chose iron as a codopant element with cobalt for extending the light absorption of $\mathrm{TiO}_{2}$ nanoparticles toward the visible region. The $\mathrm{Fe} / \mathrm{Ti}$ molar ratio of $2.5 \%$ was used in the synthesis of codoped $\mathrm{TiO}_{2}$ samples, because the higher Fe content may lead to the formation of iron oxide during thermal treatment at $180^{\circ} \mathrm{C}$, decrease the synthesis yield, and/or distort the lattice of $\mathrm{TiO}_{2}$. As shown in Table $1, \mathrm{TiO}_{2}-1 \% \mathrm{Co}-2.5 \% \mathrm{Fe}$ samples had smaller sizes (their mean particle sizes are $6.2 \mathrm{~nm}$ ) than $\mathrm{TiO}_{2}-2.5 \% \mathrm{Co}-2.5 \% \mathrm{Fe}$ samples (their mean particle sizes are $7.6 \mathrm{~nm}$ ). These results demonstrated that $\mathrm{TiO}_{2}$ codoped with $\mathrm{Co}$ and Fe inhibited the crystal growth of the particles and effectively decreased the particle size; the high doping amount of Co also resulted in an increase in the particle size of the codoped $\mathrm{TiO}_{2}$ samples.

The morphology of the synthesized $\mathrm{TiO}_{2}$ samples was further observed through FE-SEM imaging. Figure 2 presents the FE-SEM images of the representative samples: undoped $\mathrm{TiO}_{2}$ (Figures 2(a) and 2(b)), $\quad \mathrm{TiO}_{2}-1 \% \mathrm{Co}$ (Figures 2(c) and 2(d)), $\mathrm{TiO}_{2}-5 \% \mathrm{Co}$ (Figures 2(e) and 2(f )), and $\mathrm{TiO}_{2}-1 \% \mathrm{Co}-2.5 \% \mathrm{Fe}$ (Figures $2(\mathrm{~g})$ and $2(\mathrm{~h})$ ) at magnifications of $100 \mathrm{k}$ and $200 \mathrm{k}$. The results indicated that the synthesized $\mathrm{TiO}_{2}$ samples consisted of numerous crystalline particles that agglomerated to form tiny clusters. The FE-SEM images demonstrated that the particles were spherical and had uniform size distribution. The calculations from the FE-SEM images confirmed that the average sizes were 26.5, 23.8, 27, and $20.8 \mathrm{~nm}$ for undoped $\mathrm{TiO}_{2}, \mathrm{TiO}_{2}-1 \% \mathrm{Co}$, $\mathrm{TiO}_{2}-5 \% \mathrm{Co}$, and $\mathrm{TiO}_{2}-1 \% \mathrm{Co}-2.5 \% \mathrm{Fe}$ samples, respectively. These results showed deviations from the data obtained from XRD due to the agglomeration of the nanoparticles in the FE-SEM images. However, the results were in agreement with the XRD results, confirming that $\mathrm{Co}$ and Fe doping can suppress $\mathrm{TiO}_{2}$ particle growth and the $\mathrm{TiO}_{2}-1 \% \mathrm{Co}-$ $2.5 \% \mathrm{Fe}$ sample had the smallest particle size with a narrow distribution of the particle size (inset in Figure 2). 
TABle 1: Mean crystalline size and phase of the prepared $\mathrm{TiO}_{2}$ samples.

\begin{tabular}{lcccccc}
\hline Samples & Undoped $\mathrm{TiO}_{2}$ & $\mathrm{TiO}_{2}-1 \% \mathrm{Co}$ & $\mathrm{TiO}_{2}-2.5 \% \mathrm{Co}$ & $\mathrm{TiO}_{2}-5 \% \mathrm{Co}$ & $\mathrm{TiO}_{2}-1 \% \mathrm{Co}-2.5 \% \mathrm{Fe}$ & $\mathrm{TiO}{ }_{2}-2.5 \% \mathrm{Co}-2.5 \% \mathrm{Fe}$ \\
\hline Crystalline phase & Anatase & Anatase & Anatase & Anatase & Anatase & Anatase \\
Mean crystalline size & $7.8 \mathrm{~nm}$ & $6.8 \mathrm{~nm}$ & $7.4 \mathrm{~nm}$ & $7.5 \mathrm{~nm}$ & $6.2 \mathrm{~nm}$ & $7.6 \mathrm{~nm}$ \\
\hline
\end{tabular}

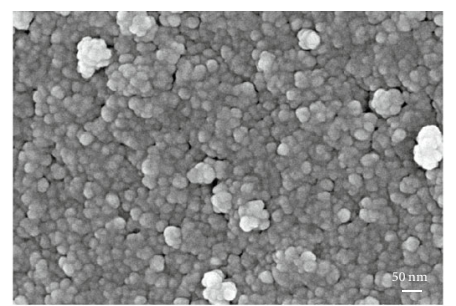

(a)

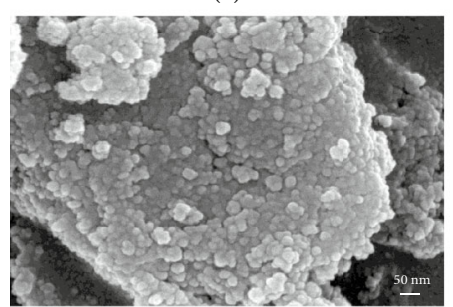

(c)

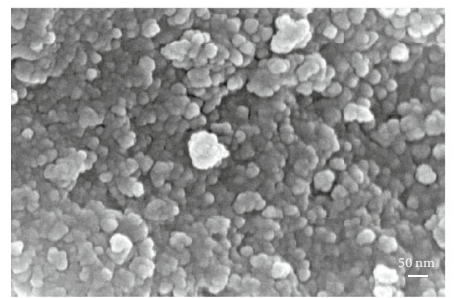

(e)

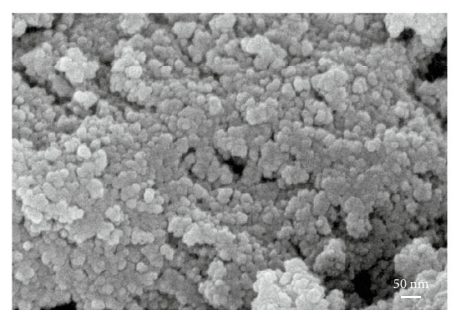

(g)

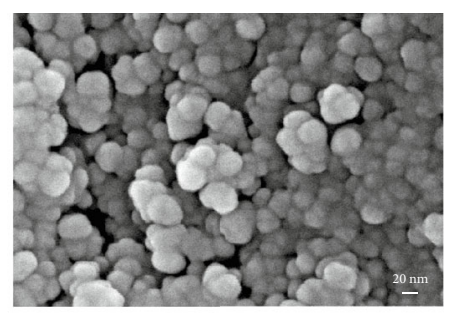

(b)

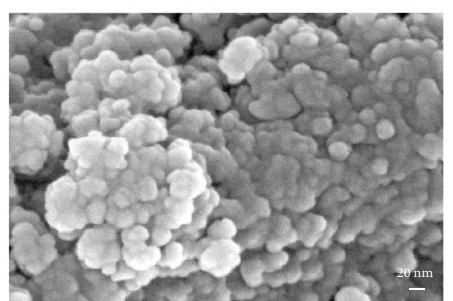

(d)

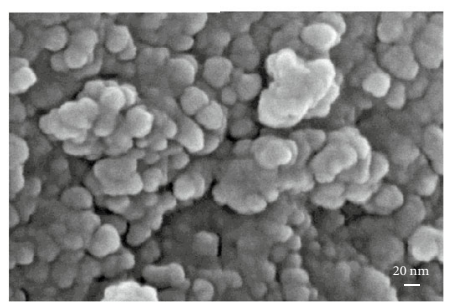

(f)

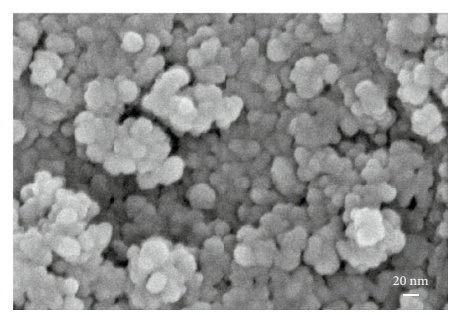

(h)

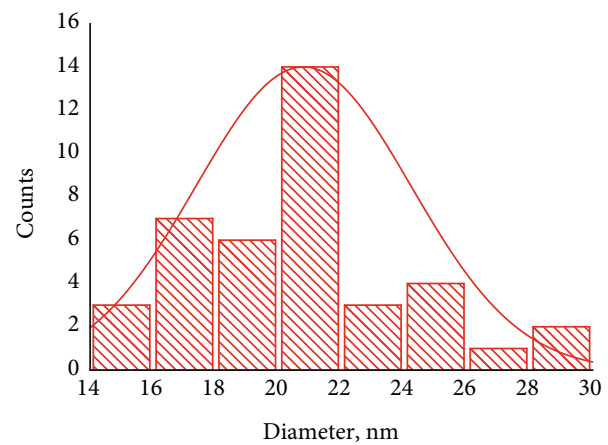

Figure 2: FE-SEM images of undoped $\mathrm{TiO}_{2}(\mathrm{a}, \mathrm{b}), \mathrm{TiO}_{2}-1 \% \mathrm{Co}(\mathrm{c}, \mathrm{d}), \mathrm{TiO}_{2}-5 \% \mathrm{Co}(\mathrm{e}, \mathrm{f})$, and $\mathrm{TiO}_{2}-1 \% \mathrm{Co}-2.5 \% \mathrm{Fe}$ (g, h) samples with magnifications of $100 \mathrm{k}$ and $200 \mathrm{k}$. Inset shows a particle size distribution of $\mathrm{TiO}_{2}-1 \% \mathrm{Co}-2.5 \% \mathrm{Fe}$ samples. 


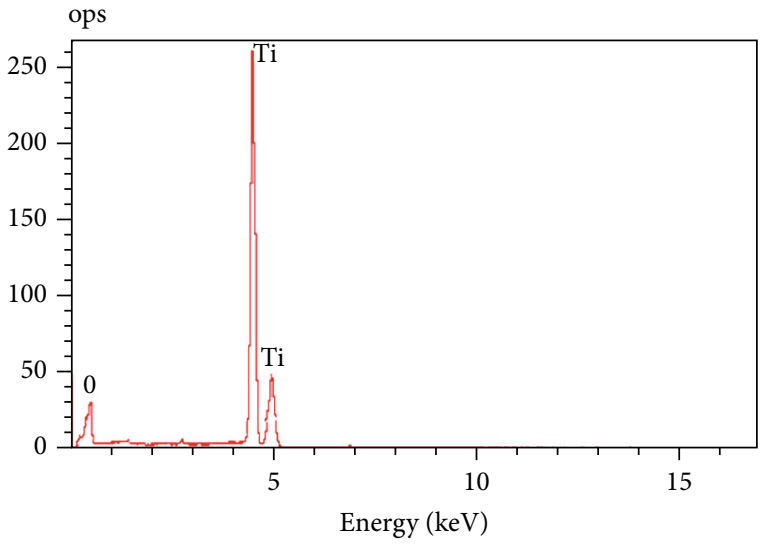

(a)

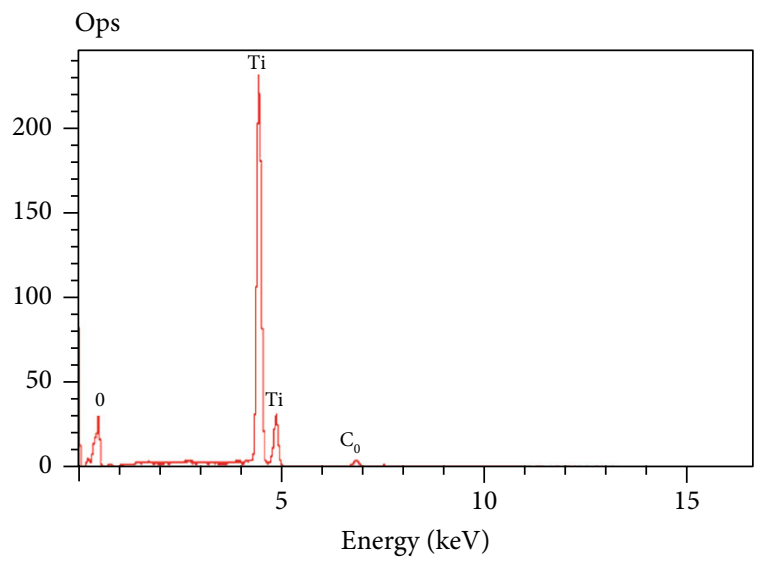

(c)

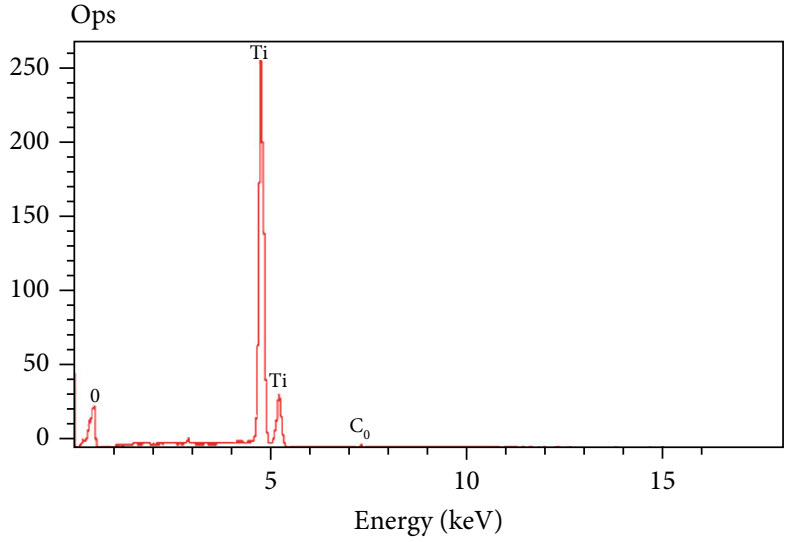

(b)

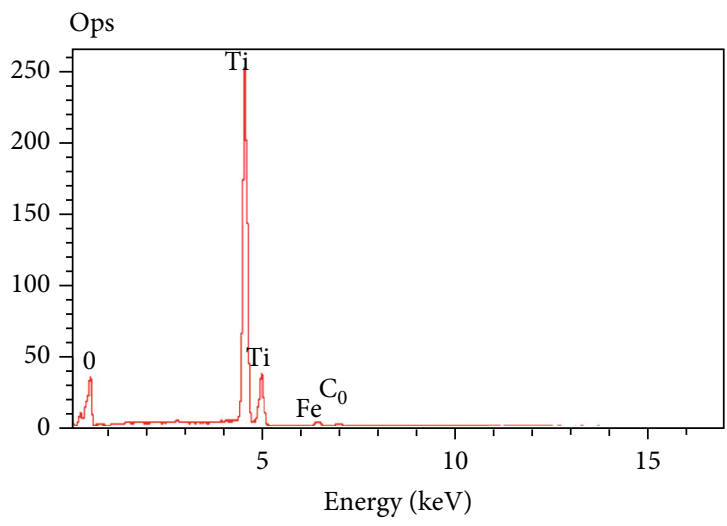

(d)

Figure 3: EDXS spectra of (a) undoped $\mathrm{TiO}_{2}$, (b) $\mathrm{TiO}_{2}-1 \% \mathrm{Co}$, (c) $\mathrm{TiO}_{2}-5 \% \mathrm{Co}$, and (d) $\mathrm{TiO}_{2}-1 \% \mathrm{Co}-2.5 \% \mathrm{Fe}$ samples.

The presence of doping metals on the $\mathrm{TiO}_{2}$ samples was determined through EDXS analyses. The EDXS spectra of the representative $\mathrm{TiO}_{2}$ samples (undoped $\mathrm{TiO}_{2}, \mathrm{TiO}_{2}$ $1 \% \mathrm{Co}, \mathrm{TiO}_{2}-5 \% \mathrm{Co}$, and $\mathrm{TiO}_{2}-1 \% \mathrm{Co}-2.5 \% \mathrm{Fe}$ ) are presented in Figure 3. As shown in Figures 3(a), O and Ti were found to be the major components of undoped $\mathrm{TiO}_{2}$ with 65.35 at $\%$ and 33.65 at\%, respectively. Co was detected as the doping component of $\mathrm{TiO}_{2}-1 \% \mathrm{Co}$ and $\mathrm{TiO}_{2}-5 \% \mathrm{Co}$ samples because tiny peaks were observed in the EDXS spectra (Figures 3(b) and 3(c)), which were attributed to the presence of Co in the samples $(0.21$ at $\%$ and 0.89 at\%, respectively). The contents of $\mathrm{Co}$ and $\mathrm{Fe}$ in $\mathrm{TiO}_{2}-1 \% \mathrm{Co}-2.5 \% \mathrm{Fe}$ samples were 0.28 at $\%$ and 0.74 at $\%$, respectively (Figure 3(d)). The results confirmed that $\mathrm{Co}$ and Fe were successfully doped in the $\mathrm{TiO}_{2}$ samples.

Nitrogen adsorption-desorption isotherms were determined for the representative samples to analyze and quantify the pore structure and surface area of doped and codoped $\mathrm{TiO}_{2}$ samples. Figure 4 presents the nitrogen adsorptiondesorption isotherms of three selected samples: $\mathrm{TiO}_{2}-1 \% \mathrm{Co}$ (Figure 4(a)), $\mathrm{TiO}_{2}-5 \% \mathrm{Co}$ (Figure 4(b)), and $\mathrm{TiO}_{2}-1 \% \mathrm{Co}-$ $2.5 \% \mathrm{Fe}$ (Figure $4(\mathrm{c})$ ). Results in Figure 4 indicate that the three samples had a similar hysteresis loop, which could be associated with capillary condensation in mesopores. The hysteresis loops of these samples, which were observed in the $P / P_{\mathrm{o}}$ range of $0.42-0.82$, were characterized by a type
IV isotherm with an $\mathrm{H}_{2}$ hysteresis loop [17]. The results suggested that the $\mathrm{TiO}_{2}$ samples contained ink-bottle pores, leading to pore blocking/percolation effects during desorption in mesopore networks. Pore size distribution was calculated by the BJH method using data on the desorption curves (Figure 5). The surface areas of the synthesized $\mathrm{TiO}_{2}$ samples were determined by using the BET method. The surface characteristics of these samples are summarized in Table 2 and compared with those of undoped $\mathrm{TiO}_{2} \cdot \mathrm{TiO}_{2}-1 \% \mathrm{Co}$ and $\mathrm{TiO}_{2}-1 \% \mathrm{Co}-2.5 \% \mathrm{Fe}$ samples showed a narrow pore size distribution (Figures 5(a) and 5(c)) with average mesopore diameters of 3.97 and $4.1 \mathrm{~nm}$, respectively (Table 2). $\mathrm{TiO}_{2}{ }^{-}$ $5 \%$ Co samples exhibited a wider pore size distribution that scattered from $2.5 \mathrm{~nm}$ to $6.5 \mathrm{~nm}$ and mainly concentrated at $5.1 \mathrm{~nm}$ (Figure 5(b) and Table 2). Undoped $\mathrm{TiO}_{2}$ showed a larger mean pore size of $6.7 \mathrm{~nm}$ than the doped and codoped $\mathrm{TiO}_{2}$. As shown in Table 2, the prepared $\mathrm{TiO}_{2}$ samples did not have significant discrepancies in their BET surface area. Relatively high BET surface areas were determined as follows: $170 \mathrm{~m}^{2} / \mathrm{g}$ for $\mathrm{TiO}_{2}-1 \% \mathrm{Co}, 164 \mathrm{~m}^{2} / \mathrm{g}$ for $\mathrm{TiO}_{2}$ $5 \% \mathrm{Co}$, and $174 \mathrm{~m}^{2} / \mathrm{g}$ for $\mathrm{TiO}_{2}-1 \% \mathrm{Co}-2.5 \% \mathrm{Fe}$, which are slightly higher than that of undoped $\mathrm{TiO}_{2}\left(160 \mathrm{~m}^{2} / \mathrm{g}\right)$. The large BET surface areas of the doped and codoped $\mathrm{TiO}_{2}$ samples confirmed the better adsorption ability of the frameworks of $\mathrm{TiO}_{2}$. This finding may be due to the linkage between the dopant ions $\left(\mathrm{Co}^{2+}\right.$ and $\left.\mathrm{Fe}^{3+}\right)$ and titanium by an 


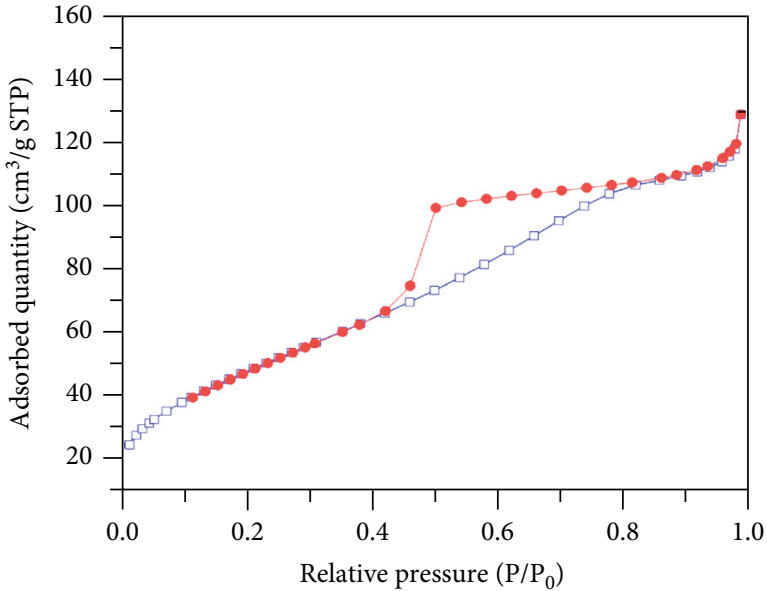

(a)

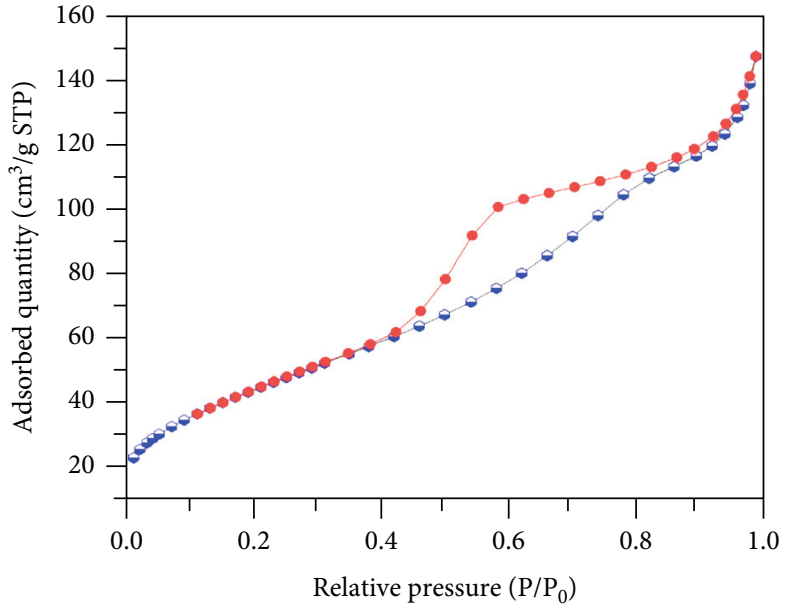

(b)

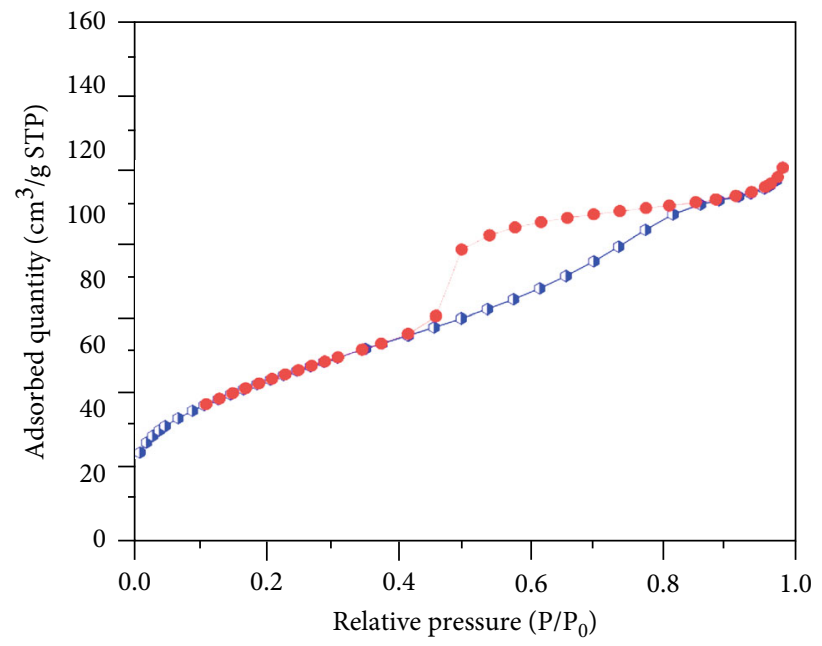

(c)

Figure 4: Nitrogen adsorption-desorption isotherms of representative samples: (a) $\mathrm{TiO}_{2}-1 \% \mathrm{Co}$, (b) $\mathrm{TiO}_{2}-5 \% \mathrm{Co}$, and (c) $\mathrm{TiO}{ }_{2}-1 \% \mathrm{Co}-$ $2.5 \%$ Fe samples.

oxygen bridge, which effectively increased their specific surface areas.

Table 3 compares the BET surface areas of doped and codoped $\mathrm{TiO}_{2}$ materials of the present work with those of other doped and codoped $\mathrm{TiO}_{2}$ materials reported previously. The BET surface areas of doped and codoped $\mathrm{TiO}_{2}$ materials of our work were within $164-174 \mathrm{~m}^{2} / \mathrm{g}$, which were higher than those of Fe-doped $\mathrm{TiO}_{2}$ materials $[18,19]$, Codoped $\mathrm{TiO}_{2}$ materials [20], $\mathrm{Cr}$ - and $\mathrm{Fe}$-doped $\mathrm{TiO}_{2}$ materials [18], and Fe- and La-doped $\mathrm{TiO}_{2}$ materials [19] (Table 3). The larger BET surface areas of the doped and codoped $\mathrm{TiO}_{2}$ materials of the present work were possibly due to their smaller particle sizes ranging from $6.2 \mathrm{~nm}$ to $7.5 \mathrm{~nm}$ (Table 3), depending on the doping amount. The doped $\mathrm{TiO}_{2}$ materials of our work were prepared under more favorable conditions (solvothermal treatment at $180^{\circ} \mathrm{C}$ without calcination). The other $\mathrm{TiO}_{2}$ materials were prepared by hydrothermal treatment or sol-gel method, followed by calcination, which resulted in the formation of larger particle sizes and significant loss of the BET surface area (Table 3 ).
The UV-vis absorption spectra of undoped $\mathrm{TiO}_{2}$, doped $\mathrm{TiO}_{2}$, and codoped $\mathrm{TiO}_{2}$ samples were recorded to study their optical properties (Figure 6). As shown in Figure 6 (curve a), the undoped $\mathrm{TiO}_{2}$ sample was characterized by a narrow absorption spectrum, ranging from $250 \mathrm{~nm}$ to $370 \mathrm{~nm}$ in the UV region. No visible light absorption was observed for the undoped $\mathrm{TiO}_{2}$ sample. Co-doped $\mathrm{TiO}_{2}$ (Figure 6, curves b-d) and $\mathrm{Co}$ - and $\mathrm{Fe}$-doped $\mathrm{TiO}_{2}$ samples (Figure 6, curves e and f) had broader absorption spectra, which shifted toward longer wavelengths in the visible light region. The absorption spectra of Co-doped $\mathrm{TiO}_{2}$ samples had maximum peaks at about 330-340 nm, but the shoulder of the peaks shifted to the visible range $(400-700 \mathrm{~nm}) . \mathrm{TiO}_{2}$ samples codoped with $\mathrm{Co}$ and Fe were characterized by a broader maximum peak at 400-500nm and stronger intensity of the absorption shoulder in the visible region compared with those of single-doped $\mathrm{TiO}_{2}$ samples. Figure 6 shows that the absorption edges of $\mathrm{TiO}_{2}$ codoped with $\mathrm{Co}$ and $\mathrm{Fe}$ moved remarkably, with a redshift to the visible region in comparison with undoped $\mathrm{TiO}_{2}$. These optical 


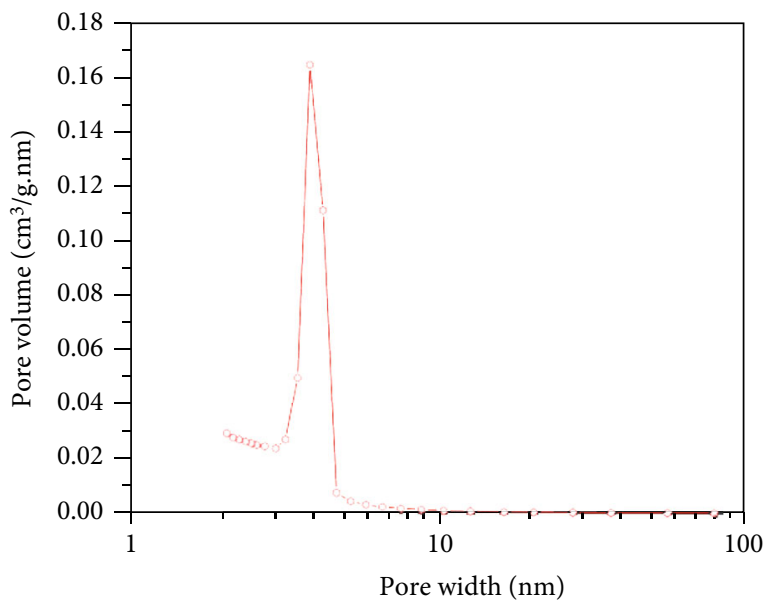

(a)

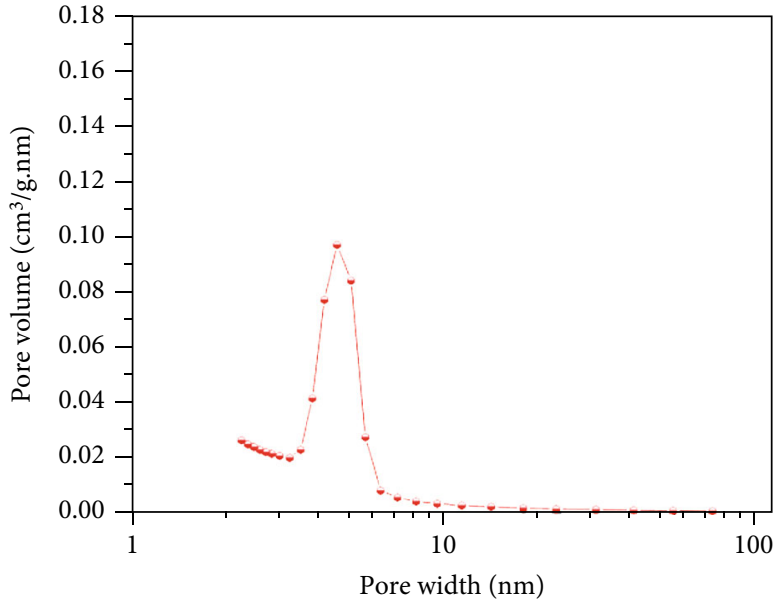

(b)

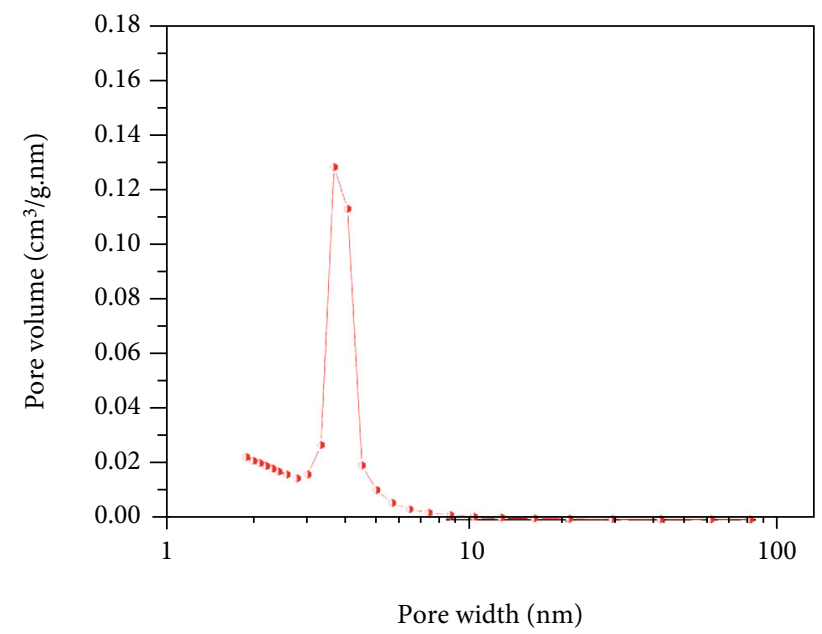

(c)

Figure 5: Pore size distributions of representative samples: (a) $\mathrm{TiO}_{2}-1 \% \mathrm{Co}$, (b) $\mathrm{TiO}_{2}-5 \% \mathrm{Co}$, and (c) $\mathrm{TiO}_{2}-1 \% \mathrm{Co}-2.5 \% \mathrm{Fe}$ samples.

TABLE 2: Surface characteristics of the representative $\mathrm{TiO}_{2}$ samples.

\begin{tabular}{lccc}
\hline Samples & $S_{\text {BET }}{ }^{\mathrm{a}}\left(\mathrm{m}^{2} / \mathrm{g}\right)$ & $V_{\mathrm{BJH}}{ }^{\mathrm{b}}\left(\mathrm{cm}^{3} / \mathrm{g}\right)$ & $D_{\mathrm{p}}{ }^{\mathrm{c}}(\mathrm{nm})$ \\
\hline $\mathrm{TiO}_{2}-1 \% \mathrm{Co}$ & 170 & 0.18 & 3.97 \\
$\mathrm{TiO}_{2}-5 \% \mathrm{Co}$ & 164 & 0.23 & 5.1 \\
$\mathrm{TiO}_{2}-1 \% \mathrm{Co}-2.5 \% \mathrm{Fe}$ & 174 & 0.16 & 4.1 \\
$\mathrm{Undoped}^{\mathrm{TiO}}$ & 160 & 0.29 & 6.7 \\
\hline
\end{tabular}

${ }^{\mathrm{a}}$ BET surface area. ${ }^{\mathrm{b}}$ Total pore volume determined using desorption curves of the isotherms. ${ }^{c}$ Peak pore sizes from the pore size distributions.

absorption characteristics of $\mathrm{TiO}_{2}$ codoped with $\mathrm{Co}$ and $\mathrm{Fe}$ were possibly due to absorption induced by dopants. The absorption edges can be extrapolated by making a tangent line of the UV-vis absorption spectra [21]. Therefore, the bandgap energies of the prepared $\mathrm{TiO}_{2}$ samples were estimated from the UV-vis spectra via the following equation:

$$
E_{g}=\frac{1240}{\lambda}
$$

The bandgap energy levels of Co-doped $\mathrm{TiO}_{2}$ samples were estimated to be $2.03 \mathrm{eV}, 2.00 \mathrm{eV}$, and $1.99 \mathrm{eV}$ (for $\mathrm{TiO}_{2}-1 \% \mathrm{Co}, \mathrm{TiO}_{2}-2.5 \% \mathrm{Co}$, and $\mathrm{TiO}_{2}-5 \% \mathrm{Co}$, respectively), which were higher than those of Co- and Fe-codoped $\mathrm{TiO}_{2}$ samples (their bandgap energies are $1.65 \mathrm{eV}$ and $1.59 \mathrm{eV}$ for $\mathrm{TiO}_{2}-1 \% \mathrm{Co}-2.5 \% \mathrm{Fe}$ and $\mathrm{TiO}_{2}-2.5 \% \mathrm{Co}-2.5 \% \mathrm{Fe}$, respectively). The calculated bandgap energies of single-doped and codoped $\mathrm{TiO}_{2}$ samples were lower than that of undoped $\mathrm{TiO}_{2}$ samples $(\sim 3.25 \mathrm{eV})$. The results revealed that the dopant elements were successfully incorporated into the $\mathrm{TiO}_{2}$ crystal lattice and extended the optical absorption toward the visible light region. $\mathrm{TiO}_{2}$ samples codoped with $\mathrm{Co}$ and Fe had stronger optical absorption of the visible light than single-doped and undoped $\mathrm{TiO}_{2}$ samples. This means that the $\mathrm{TiO}_{2}$ codoped with $\mathrm{Co}$ and $\mathrm{Fe}$ can absorb visible light in a much wider range of wavelengths than undoped $\mathrm{TiO}_{2}$ and single-doped $\mathrm{TiO}_{2}$ samples, which is beneficial for increasing the photocatalytic efficiency under visible light.

3.2. Photocatalytic Activities of the Prepared $\mathrm{TiO}_{2}$ Materials for Degradation of $M B$. Before the photocatalytic reaction, the adsorption for $\mathrm{MB}$ removal on the synthesized $\mathrm{TiO}_{2}$ materials was conducted under dark conditions. Results 
TABLE 3: Comparison of the BET surface areas of the $\mathrm{TiO}_{2}$ samples prepared in this work with those of previous works.

\begin{tabular}{|c|c|c|c|c|}
\hline Materials & Synthetic conditions & $S_{\mathrm{BET}}\left(\mathrm{m}^{2} / \mathrm{g}\right)$ & Particle size $(\mathrm{nm})$ & References \\
\hline $\mathrm{TiO}_{2}-1 \% \mathrm{Co}$ & Solvothermal treatment at $180^{\circ} \mathrm{C}$ without calcination & 170 & 6.8 & This work \\
\hline $\mathrm{TiO}_{2}-5 \% \mathrm{Co}$ & Solvothermal treatment at $180^{\circ} \mathrm{C}$ without calcination & 164 & 7.5 & This work \\
\hline $\mathrm{TiO}_{2}-1 \% \mathrm{Co}-2.5 \% \mathrm{Fe}$ & Solvothermal treatment at $180^{\circ} \mathrm{C}$ without calcination & 174 & 6.2 & This work \\
\hline $\mathrm{TiO}_{2}-\mathrm{Fe}$ & Hydrothermal treatment at $180^{\circ} \mathrm{C}$, calcined at $400^{\circ} \mathrm{C}$ & 89 & 18 & {$[18]$} \\
\hline $\mathrm{TiO}_{2}-0.2 \% \mathrm{Fe}$ & Sol-gel, calcined at $500^{\circ} \mathrm{C}$ & 78 & 12 & [19] \\
\hline $\mathrm{TiO}_{2}-0.2 \% \mathrm{Fe}-2 \% \mathrm{La}$ & Sol-gel, calcined at $500^{\circ} \mathrm{C}$ & 84 & 10 & [19] \\
\hline $\mathrm{TiO} 2-0.085 \% \mathrm{Co}$ & Sol-gel, with following heat treatment from $200^{\circ} \mathrm{C}$ to $900^{\circ} \mathrm{C}$ for $30 \mathrm{~min}$ & 39.7 & 25 & {$[20]$} \\
\hline Fe-Cr-codoped $\mathrm{TiO}_{2}$ & Hydrothermal treatment at $180^{\circ} \mathrm{C}$, calcined $500^{\circ} \mathrm{C}$ & 93 & & {$[18]$} \\
\hline
\end{tabular}

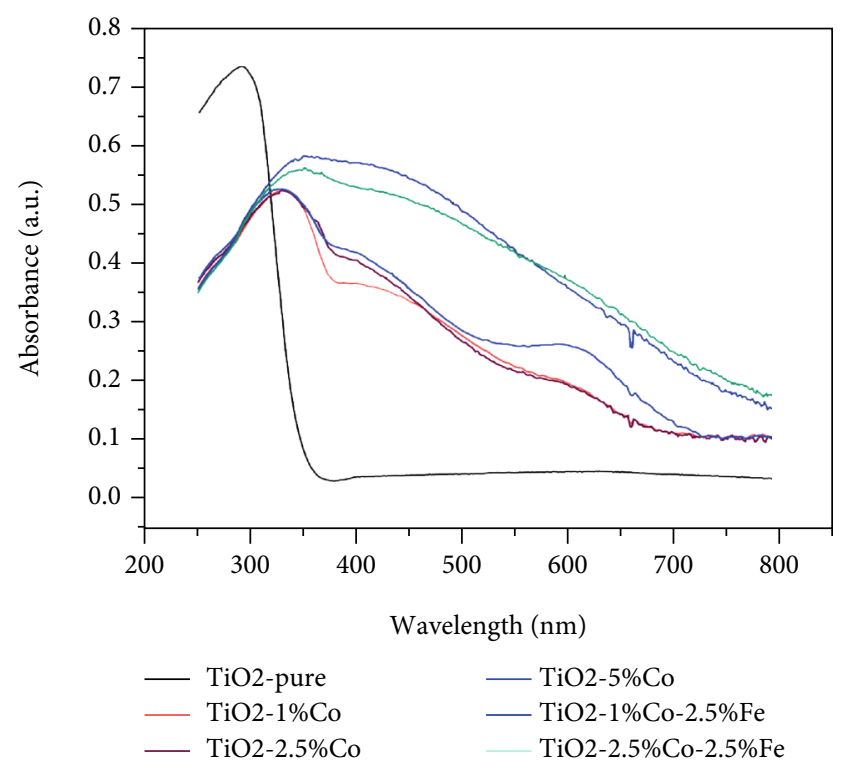

Figure 6: UV-vis spectra of undoped $\mathrm{TiO}_{2}, \mathrm{TiO}_{2}-1 \% \mathrm{Co}, \mathrm{TiO}_{2^{-}}$ $2.5 \% \mathrm{Co}, \mathrm{TiO}_{2}-5 \% \mathrm{Co}, \mathrm{TiO}_{2}-1 \% \mathrm{Co}-2.5 \% \mathrm{Fe}$, and $\mathrm{TiO}_{2}-2.5 \% \mathrm{Co}-$ $2.5 \% \mathrm{Fe}$ samples.

obtained showed that the percentages of $\mathrm{MB}$ removal were only 5\%-6\% after $60 \mathrm{~min}$ for all the synthesized materials, but desorption of $\mathrm{MB}$ was observed by prolonging adsorption time for those materials. Therefore, the photocatalytic activities of the prepared $\mathrm{TiO}_{2}$ samples were evaluated by degrading $\mathrm{MB}$ solution under visible light irradiation. The reaction mixture was first stirred in the dark for $30 \mathrm{~min}$ to reach the adsorption-desorption equilibrium and to ensure that the degradation of $\mathrm{MB}$ obtained is due to the photocatalytic reaction with the presence of the synthesized $\mathrm{TiO}_{2}$ materials, but not due to the adsorption. Figure 7 shows the percentage of $\mathrm{MB}$ degradation over all of the $\mathrm{TiO}_{2}$ samples (undoped $\mathrm{TiO}_{2}, \mathrm{TiO}_{2}-1 \% \mathrm{Co}, \mathrm{TiO}_{2}-2.5 \% \mathrm{Co}, \mathrm{TiO}_{2^{-}}$ $5 \% \mathrm{Co}, \mathrm{TiO}_{2}-1 \% \mathrm{Co}-2.5 \% \mathrm{Fe}$, and $\mathrm{TiO}_{2}-2.5 \% \mathrm{Co}-2.5 \% \mathrm{Fe}$ samples) as a function of irradiation time. For comparison, control experiments were performed under the same conditions but without the presence of a photocatalyst (Figure 7, curve $\mathrm{MB})$. As shown in Figure 7 (curve MB), almost no degradation of $\mathrm{MB}$ was observed without the photocatalyst (only $7.95 \%$ of $\mathrm{MB}$ was degraded after $120 \mathrm{~min}$ of exposure to visible light irradiation), indicating that $\mathrm{MB}$ was unable to self- degrade. Undoped $\mathrm{TiO}_{2}$ and $\mathrm{Co}$-doped $\mathrm{TiO}_{2}$ with low doping concentration $\left(\mathrm{TiO}_{2}-1 \% \mathrm{Co}\right.$ and $\left.\mathrm{TiO}_{2}-2.5 \% \mathrm{Co}\right)$ showed pure photocatalytic activity. The degradation efficiencies of $\mathrm{MB}$ on undoped $\mathrm{TiO}_{2}$ samples were comparable with those of Co-doped $\mathrm{TiO}_{2}$ samples with low Co doping concentration for all the tested time points (Figure 7, curves undoped $\mathrm{TiO}_{2}, \mathrm{TiO}_{2}-1 \% \mathrm{Co}$, and $\mathrm{TiO}_{2}-2.5 \% \mathrm{Co}$ ). The degradation percentages of $\mathrm{MB}$ were $10.95 \%, 17.85 \%$, and $17.5 \%$ after $120 \mathrm{~min}$ of irradiation for undoped $\mathrm{TiO}_{2}, \mathrm{TiO}_{2}-1 \% \mathrm{Co}$, and $\mathrm{TiO}_{2}-2.5 \% \mathrm{Co}$, respectively. However, the degradation of $\mathrm{MB}$ is enhanced with higher Co doping concentration. The degradation percentages of $\mathrm{MB}$ increased three times on $\mathrm{TiO}_{2}-5 \% \mathrm{Co}$ samples and were higher than those on $\mathrm{TiO}_{2}$ $1 \% \mathrm{Co}$ and $\mathrm{TiO}_{2}-2.5 \% \mathrm{Co}$ samples for all the tested time points. About $39.8 \%$ of $\mathrm{MB}$ was degraded within $30 \mathrm{~min}$ on $\mathrm{TiO}_{2}-5 \% \mathrm{Co}$ and then gradually increased to $\sim 50 \%$ by increasing irradiation time up to $120 \mathrm{~min}$. Moreover, the significantly enhanced degradation of $\mathrm{MB}$ was observed on codoped $\mathrm{TiO}_{2}$ samples (Figure 7, curves $\mathrm{TiO}_{2}-1 \% \mathrm{Co}-$ $2.5 \% \mathrm{Fe}$ and $\left.\mathrm{TiO}_{2}-2.5 \% \mathrm{Co}-2.5 \% \mathrm{Fe}\right)$. The highest degradation of $\mathrm{MB}$ was obtained by $\mathrm{TiO}_{2}$ codoped with $1 \% \mathrm{Co}$ and $2.5 \% \mathrm{Fe}$ for all the time points tested. The degradation of $\mathrm{MB}$ was almost complete on codoped $\mathrm{TiO}_{2}$ samples for the tested time; $90 \%$ and $85 \%$ of $\mathrm{MB}$ were degraded on $\mathrm{TiO}_{2}$ $1 \% \mathrm{Co}-2.5 \% \mathrm{Fe}$ and $\mathrm{TiO}_{2}-2.5 \% \mathrm{Co}-2.5 \% \mathrm{Fe}$ after $120 \mathrm{~min}$, respectively.

The results showed that $\mathrm{TiO}_{2}$ samples codoped with Co and $\mathrm{Fe}$ exhibited higher photocatalytic degradation of $\mathrm{MB}$ under visible light than the undoped and single-doped $\mathrm{TiO}_{2}$ samples, which could be attributed to their lower bandgap values compared to those of the undoped and singledoped $\mathrm{TiO}_{2}$ samples. These observations indicated that codopant ions had a favorable effect on the photocatalytic performance of the prepared $\mathrm{TiO}_{2}$ materials. These ions can provide additional energy levels within the bandgap of $\mathrm{TiO}_{2}$. The bandgap of $\mathrm{TiO}_{2}$ consists of a contribution from the $2 \mathrm{p}$ orbitals of $\mathrm{O}$ for the valence band and the $3 \mathrm{~d}$ orbitals of Ti toward the conduction band, which have a large difference in energy, leading to the activation of $\mathrm{TiO}_{2}$ in the UV light region with extremely high energy. The band structures of codoped $\mathrm{TiO}_{2}$ materials are mainly affected by the $3 \mathrm{~d}$ energy states of the transitional metal ions $\left(\mathrm{Co}^{2+}\right.$ and $\mathrm{Fe}^{3+}$ ). In fact, the UV-vis absorption studies (Figure 6) revealed that the respective absorption bands of codoped $\mathrm{TiO}_{2}$ samples effectively shifted toward wavelengths longer 


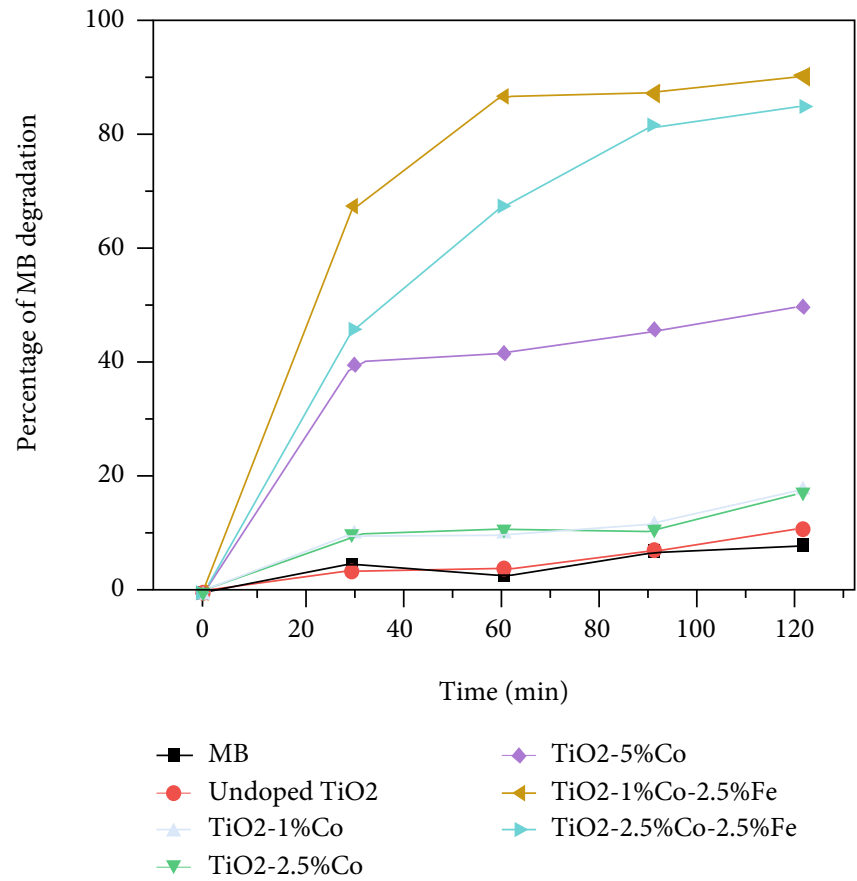

Figure 7: The degradation of $\mathrm{MB}$ using different catalysts: undoped $\mathrm{TiO}_{2}, \mathrm{TiO}_{2}-1 \% \mathrm{Co}, \mathrm{TiO}_{2}-2.5 \% \mathrm{Co}, \mathrm{TiO}_{2}-5 \% \mathrm{Co}, \mathrm{TiO}-1 \% \mathrm{Co}-2.5 \% \mathrm{Fe}$, and $\mathrm{TiO}_{2}-2.5 \% \mathrm{Co}-2.5 \% \mathrm{Fe}$ samples under visible light irradiation.

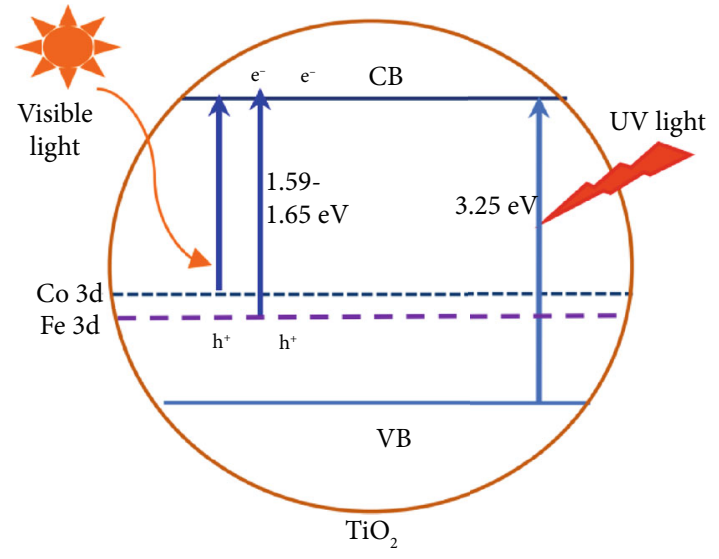

Scheme 1: Band structure of $\mathrm{TiO}_{2}$ and $\mathrm{TiO}_{2}$ codoped with $\mathrm{Co}^{2+}$ and $\mathrm{Fe}^{3+}$. $\mathrm{VB}$ : valence band; $\mathrm{CB}$ : conduction band.

than $400 \mathrm{~nm}$. Thus, the partially filled $\mathrm{Co} / \mathrm{Fe} 3 \mathrm{~d}$ bands were located below the conduction band of $\mathrm{TiO}_{2}$. Hence, when photons with wavelengths longer than $400 \mathrm{~nm}$ are used for illumination, the electrons in the Co $3 \mathrm{~d}$ and Fe $3 \mathrm{~d}$ bands, instead of electrons in the valence band of $\mathrm{TiO}_{2}$, are excited to the conduction band, while $\mathrm{Co}^{2+}$ and $\mathrm{Fe}^{3+}$ loses one electron and becomes $\mathrm{Co}^{3+}$ and $\mathrm{Fe}^{4+}$ (see Scheme 1). This phenomenon can induce more photogenerated electrons and holes to participate in the photocatalytic reaction.

As calculated above, the bandgap energy values of codoped $\mathrm{TiO}_{2}$ samples $(1.59 \mathrm{eV}-1.65 \mathrm{eV})$ were lower than those of single-doped $\mathrm{TiO}_{2}$ samples $(1.99-2.03 \mathrm{eV})$ and undoped $\mathrm{TiO}_{2}(3.25 \mathrm{eV})$, indicating the lower energy of pho- tons necessary to generate electron transition and holes $\left(h^{+}\right)$ for codoped $\mathrm{TiO}_{2}$ samples compared to single-doped and undoped $\mathrm{TiO}_{2}$. These holes can react with water to produce the highly reactive $\mathrm{OH}$, and both holes and $\mathrm{OH}$ have a strong oxidation potential for the degradation of MB.

The plausible reaction mechanism of the photodegradation is given below:

$$
\begin{gathered}
\mathrm{TiO}_{2}+h v \longrightarrow e^{-}+h^{+} \\
\mathrm{Co}^{2+}+h v \longrightarrow \mathrm{Co}^{3+}+e^{-} \\
\mathrm{Fe}^{3+}+h v \longrightarrow \mathrm{Fe}^{4+}+e^{-} \\
h^{+}+\mathrm{H}_{2} \mathrm{O}_{\text {ads }} \longrightarrow \cdot \mathrm{OH}+\mathrm{H}^{+} \\
e^{-}+\mathrm{O}_{2 \text { ads }} \longrightarrow \mathrm{O}_{2} \cdot{ }^{-} \\
\mathrm{MB}+\cdot \mathrm{OH} / \mathrm{O}_{2} \cdot{ }^{-} \longrightarrow \text { degradation products }
\end{gathered}
$$

It is suggested that the photodegradation of $\mathrm{MB}$ can be divided into three main steps: (1) the initial step is the formation of electrons $\left(e^{-}\right)$in the $\mathrm{CB}$ and holes $\left(h^{+}\right)$in the $\mathrm{VB}$ upon a light incident on the photocatalyst surface (see equations (4), (5), (6)); (2) the intermediate step includes the formation of $\mathrm{OH}$ and $\mathrm{H}^{+}$through the interaction between the holes and $\mathrm{H}_{2} \mathrm{O}$ adsorbed on the photocatalyst surface (equation (7)) and of $\mathrm{O}_{2}{ }^{--}$due to the reduction of the adsorbed $\mathrm{O}_{2}$ molecule (equation (8)) that has strong oxidation power, which in turn promotes the decomposition of $\mathrm{MB}$; and (3) the final step is the degradation of $\mathrm{MB}$ by $\mathrm{OH} / \mathrm{O}_{2}{ }^{--}$radicals. 


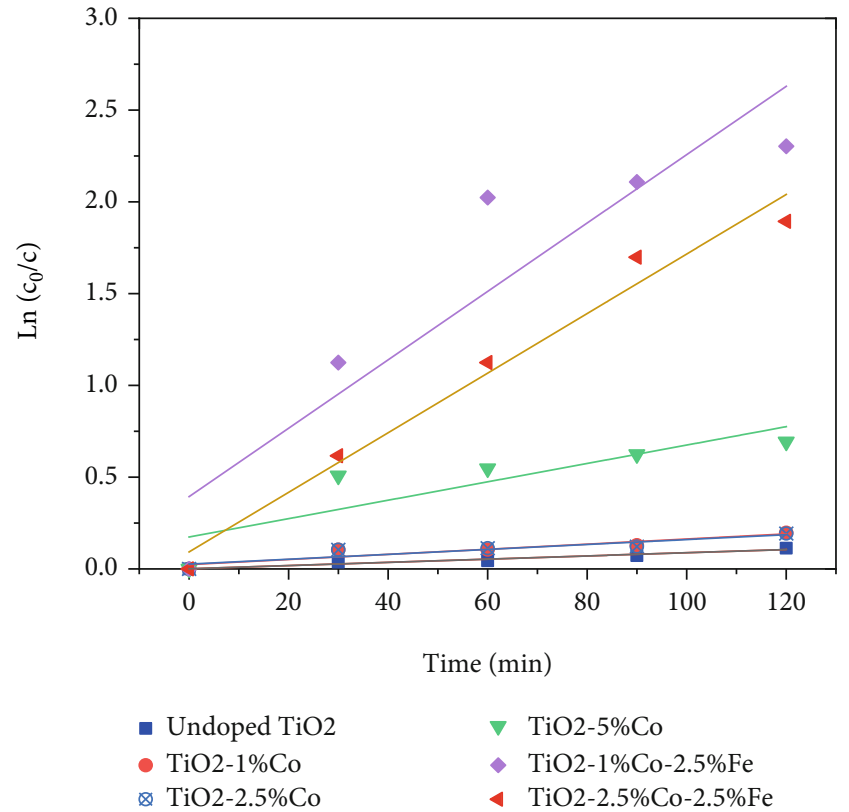

(a)

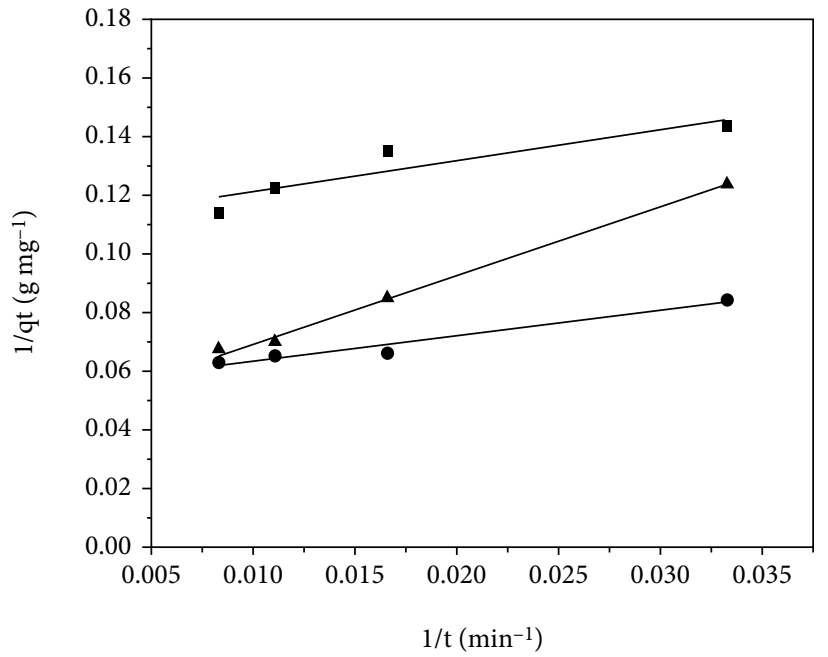

- $\mathrm{TiO} 2-5 \% \mathrm{Co}$

- $\mathrm{TiO} 2-1 \% \mathrm{Co}-2.5 \% \mathrm{Fe}$

\ $\mathrm{TiO} 2-2.5 \% \mathrm{Co}-2.5 \% \mathrm{Fe}$

Figure 8: Plots of (a) first- and (b) second-order reaction rates for the degradation of $\mathrm{MB}$ over as-prepared $\mathrm{TiO}_{2}$ materials.

Thus, this work proposed a study to understand the role of $\mathrm{Co}$ and $\mathrm{Fe}$ in codoped $\mathrm{TiO}_{2}$ nanoparticles in yielding better performance as a visible light-driven photocatalyst.

The kinetics of photodegradation of $\mathrm{MB}$ on as-prepared $\mathrm{TiO}_{2}$ materials was further investigated using the pseudofirst-order kinetic model [22] as follows:

$$
\ln \frac{C_{\mathrm{o}}}{C}=k_{1} t
$$

where $C_{\mathrm{o}}$ is the initial concentration of $\mathrm{MB}, C$ is the concentration of $\mathrm{MB}$ at time $t$, and $k_{1}$ is the apparent reaction rate constant. According to equation (10), a linear regression plot of $\ln \left(C_{\mathrm{o}} / C\right)$ vs. time $t$ gives the value of $k_{1}$. The experimental data were analyzed using the pseudo-first-order equation; the resulting plots of $\ln \left(C_{0} / C\right)$ vs. time $t$ are shown in Figure 8(a). From the obtained plots in Figure 8(a), the rate constants were found to be $0.0009 \mathrm{~min}^{-1}, 0.0014 \mathrm{~min}^{-1}$, $0.0013 \mathrm{~min}^{-1}, 0.005 \mathrm{~min}^{-1}, 0.0186 \mathrm{~min}^{-1}$, and $0.0162 \mathrm{~min}^{-1}$ with correlation coefficients $\left(R^{2}\right)$ of $0.96,0.91,0.90,0.78$, 0.85 , and 0.98 for the undoped $\mathrm{TiO}_{2}, \mathrm{TiO}_{2}-1 \% \mathrm{Co}, \mathrm{TiO}_{2}-$ $2.5 \% \mathrm{Co}, \quad \mathrm{TiO}_{2}-5 \% \mathrm{Co}, \quad \mathrm{TiO}_{2}-1 \% \mathrm{Co}-2.5 \% \mathrm{Fe}$, and $\mathrm{TiO}_{2}-$ $2.5 \% \mathrm{Co}-2.5 \% \mathrm{Fe}$, respectively. The experimental degradation data of all the $\mathrm{TiO}_{2}$ samples were also analyzed using the pseudo-second-order kinetic equation proposed by Blanchard et al. [23]:

$$
\frac{1}{q_{t}}=\frac{1}{t} \frac{1}{k_{2} q_{e}^{2}}+\frac{1}{q_{e}}
$$

where $q_{t}$ and $q_{e}$ are the amounts of dye adsorbed at time $t$ and at equilibrium $\left(\mathrm{mg}^{-1} \mathrm{~g}^{-1}\right)$ and $k_{2}$ is the pseudo-secondorder rate constant $\left(\mathrm{g} \cdot \mathrm{mg}^{-1} \cdot \mathrm{min}^{-1}\right)$ for the adsorption pro- cess. The linear plots of $1 / q_{t}$ vs. time $1 / t$ shown in Figure 8(b) give the values of $k_{2}$ and $q_{e}$. It could be seen that three $\mathrm{TiO}_{2}$ samples: $\mathrm{TiO}_{2}-5 \% \mathrm{Co}, \mathrm{TiO}_{2}-1 \% \mathrm{Co}-2.5 \% \mathrm{Fe}$, and $\mathrm{TiO}_{2}-2.5 \% \mathrm{Co}-2.5 \% \mathrm{Fe}$ showed the best fit in the linear plots of $1 / q_{t}$ vs. $1 / t$ with higher values of $R^{2}(0.83,0.95$, and 0.99 , respectively) than those of the pseudo-first-order equation $(0.78,0.85$, and 0.98$)$. The values of $q_{e}$ obtained from the linear plots are $9.03 \mathrm{mg} \cdot \mathrm{g}^{-1}, 18.28 \mathrm{mg} \cdot \mathrm{g}^{-1}$, and $21.78 \mathrm{mg} \cdot \mathrm{g}^{-1}$ for $\mathrm{TiO}_{2}-5 \% \mathrm{Co}$, $\mathrm{TiO}_{2}-1 \% \mathrm{Co}-2.5 \% \mathrm{Fe}$, and $\mathrm{TiO}_{2}-2.5 \% \mathrm{Co}-2.5 \% \mathrm{Fe}$, which were higher than those of the experimental values $\left(8.75 \mathrm{mg} \cdot \mathrm{g}^{-1}, \quad 14.86 \mathrm{mg} \cdot \mathrm{g}^{-1}\right.$, and $15.75 \mathrm{mg} \cdot \mathrm{g}^{-1}$ for $\mathrm{TiO}_{2}-5 \% \mathrm{Co}, \mathrm{TiO}_{2}-1 \% \mathrm{Co}-2.5 \% \mathrm{Fe}$, and $\mathrm{TiO}_{2}-2.5 \% \mathrm{Co}-2.5 \% \mathrm{Fe}$, respectively), whereas the undoped $\mathrm{TiO}_{2}, \mathrm{TiO}_{2}-1 \% \mathrm{Co}$, and $\mathrm{TiO}_{2}-2.5 \%$ Co samples did not follow the pseudo-second-order equation because of smaller values of $R^{2}(0.82,0.55$, and 0.54$)$ of the plots $1 / q_{t}$ vs. $1 / t$ (not shown), compared to those of the pseudo-first-order plots.

The observations revealed that the degradation of $\mathrm{MB}$ on the undoped $\mathrm{TiO}_{2}$ and $\mathrm{Co}$ single-doped $\mathrm{TiO}_{2}$ samples with $1 \%$ Co and $2.5 \%$ Co doping can be described by the pseudo-first-order equation. Meanwhile, the pseudo-second order fits better compared to the pseudo-first order for describing the degradation of $\mathrm{MB}$ on the $\mathrm{TiO}_{2}$ doped with $5 \% \mathrm{Co}$ and codoped with $\mathrm{Co}$ and $\mathrm{Fe}$, considering that $R^{2}$ of the pseudo-second-order equation was greater than that of the first order for those samples. This clearly explains that the enhanced degradation efficiency of $\mathrm{MB}$ is attributed to the high surface area of the $\mathrm{TiO}_{2}$ codoped with $\mathrm{Co}$ and $\mathrm{Fe}$ and their reduced bandgap energies.

Table 4 compares the degradation of $\mathrm{MB}$ on the $\mathrm{TiO}_{2}$ materials as prepared in this work with those published in previous works [24-28]. It was found that the $\mathrm{TiO}_{2}$ codoped with $1 \% \mathrm{Co}$ and $2.5 \% \mathrm{Fe}$ in this work showed the highest 
TABLE 4: Comparison of $\mathrm{MB}$ degradation of the $\mathrm{TiO}_{2}$-codoped samples of this work with other materials.

\begin{tabular}{|c|c|c|c|c|}
\hline Materials & Synthetic conditions & $S_{\mathrm{BET}}\left(\mathrm{m}^{2} \cdot \mathrm{g}^{-1}\right)$ & Degradation percentage of $\mathrm{MB}$ & References \\
\hline $\mathrm{Bi}_{2} \mathrm{O}_{3}$ & Calcination method at $500^{\circ} \mathrm{C}$ for $6 \mathrm{~h}$ & 2.9 & $\begin{array}{c}70 \% \text { after } 4 \mathrm{~h} \text { under visible light } \\
\text { irradiation }\end{array}$ & {$[24]$} \\
\hline $\mathrm{CaBi}_{6} \mathrm{O}_{10}$ & $\begin{array}{l}\text { Impregnation-calcination method at } 650^{\circ} \mathrm{C} \text { for } \\
\qquad 12 \mathrm{~h}\end{array}$ & 2.5 & $\begin{array}{l}97 \% \text { after } 4 \mathrm{~h} \text { under visible light } \\
\text { irradiation }\end{array}$ & {$[24]$} \\
\hline $\mathrm{CeO}_{2} / \mathrm{V}_{2} \mathrm{O}_{5}$ & Thermal decomposition at $400^{\circ} \mathrm{C}$ for $30 \mathrm{~min}$ & - & $64.2 \%$ after $4 \mathrm{~h}$ under visible light & {$[25]$} \\
\hline $\mathrm{CeO}_{2} / \mathrm{CuO}$ & Thermal decomposition at $400^{\circ} \mathrm{C}$ for $30 \mathrm{~min}$ & - & $70.1 \%$ after $4 \mathrm{~h}$ under visible light & {$[25]$} \\
\hline $\mathrm{ZnO} / \mathrm{CdO}$ & Thermal decomposition at $350^{\circ} \mathrm{C}$ for $3 \mathrm{~h}$ & - & $75 \%$ after $4 \mathrm{~h}$ under visible light & {$[26]$} \\
\hline $\mathrm{g}-\mathrm{C}_{3} \mathrm{~N}_{4}-\mathrm{CdS}$ & Precipitation method & 166.5 & $90.45 \%$ after $3 \mathrm{~h}$ under visible light & {$[27]$} \\
\hline F-doped $\mathrm{TiO}_{2}$ & Sol-gel method, calcined at $500^{\circ} \mathrm{C}$ for $1 \mathrm{~h}$ & 39.6 & $90 \%$ after $4 \mathrm{~h}$ under visible light & {$[28]$} \\
\hline $\begin{array}{l}\mathrm{TiO}_{2}-1 \% \mathrm{Co}- \\
2.5 \% \mathrm{Fe}\end{array}$ & Solvothermal method at $180^{\circ} \mathrm{C}$ & 174 & $90 \%$ after $2 \mathrm{~h}$ under visible light & This work \\
\hline
\end{tabular}

photocatalytic efficiency with $90 \%$ of $\mathrm{MB}$ degraded after visible light irradiation of $2 \mathrm{~h}$. The metal oxide $\left(\mathrm{Bi}_{2} \mathrm{O}_{3}\right)$ [24] and mixed metal oxides (e.g., $\mathrm{CeO}_{2} / \mathrm{V}_{2} \mathrm{O}_{5}$ [24], $\mathrm{CeO}_{2} / \mathrm{CuO}$ [25], and $\mathrm{ZnO} / \mathrm{CdO}[26])$ exhibited much lower degradation efficiency of $\mathrm{MB}$ compared with the $\mathrm{TiO}_{2}$ materials of our work, which degraded about $64.2 \%-75 \%$ of $\mathrm{MB}$ for a longer irradiation time of $4 \mathrm{~h}$. The complex metal oxide $\mathrm{CaBi}_{6} \mathrm{O}_{10}$ [24] and nanocomposite $\mathrm{g}-\mathrm{C}_{3} \mathrm{~N}_{4}$-CdS [27] demonstrated relatively high degradation percentages of $\mathrm{MB}(\sim 97 \%$ and $90.45 \%$ for $\mathrm{CaBi}_{6} \mathrm{O}_{10}$ and $\mathrm{g}-\mathrm{C}_{3} \mathrm{~N}_{4}$-CdS, respectively), which could be comparable with that of the $\mathrm{TiO}_{2}$ codoped with $1 \% \mathrm{Co}$ and $2.5 \% \mathrm{Fe}$ of our work, but these materials require a quite long irradiation time of $4 \mathrm{~h}$ (for $\mathrm{CaBi}_{6} \mathrm{O}_{10}$ ) and $3 \mathrm{~h}$ $\left(\mathrm{g}-\mathrm{C}_{3} \mathrm{~N}_{4}-\mathrm{CdS}\right)$ to obtain the complete degradation of $\mathrm{MB}$ under visible light. Moreover, a similar study reported that $\mathrm{TiO}_{2}$ doped with $10 \% \mathrm{~F}$ [28] also revealed a high degradation percentage of $\mathrm{MB}(\sim 90 \%)$, but after a much longer irradiation time of $4 \mathrm{~h}$, compared to that of the $\mathrm{TiO}_{2}$ codoped with $\mathrm{Co}$ and Fe of our work. The comparison revealed that the photocatalytic efficiency of the materials depends not only on their band structure but also on their surface characteristics. The excellent photocatalytic performance of the $\mathrm{TiO}_{2}$ codoped with $\mathrm{Co}$ and Fe of our work could be attributed to their larger BET surface area compared to those of the other materials. As a result, the $\mathrm{TiO}_{2}$ codoped with $\mathrm{Co}$ and Fe has more active sites and simultaneously can absorb much more visible light and generate more electron-hole pairs, which in turn enhanced the photocatalytic activity and reduced the reaction time as compared to the other materials.

\section{Conclusions}

In this work, we presented the characterization of $\mathrm{TiO}_{2}$ nanoparticles codoped with $\mathrm{Co}^{2+}$ and $\mathrm{Fe}^{3+}$ synthesized through solvothermal treatment at $180^{\circ} \mathrm{C}$ without further calcination at high temperatures. Undoped $\mathrm{TiO}_{2}$ and $\mathrm{Co}$ single-doped $\mathrm{TiO}_{2}$ materials were also prepared using the same procedure to compare with codoped $\mathrm{TiO}_{2}$ in terms of optical absorption and photocatalytic efficiency for $\mathrm{MB}$ degradation. The doped and codoped $\mathrm{TiO}_{2}$ materials of the present work exhibited better adsorption characteristics (e.g., their BET surface areas of $164-174 \mathrm{~m}^{2} / \mathrm{g}$ ) than doped and codoped $\mathrm{TiO}_{2}$ materials of previous works; asprepared codoped $\mathrm{TiO}_{2}$ materials had significantly enhanced optical adsorption toward the visible light region. Among the $\mathrm{TiO}_{2}$ samples studied, the codoped $\mathrm{TiO}_{2}$ materials showed the highest photocatalytic activity for the degradation of $\mathrm{MB}$; they degraded about $90 \%$ of $\mathrm{MB}$ within 120 min under visible light irradiation. The $\mathrm{TiO}_{2}$ samples codoped with $\mathrm{Co}$ and $\mathrm{Fe}$ in this work showed higher photocatalytic efficiency for the degradation of MB than those of metal oxides, mixed metal oxides, and other materials in the previous works. The pseudo-second-order kinetic model fits well for describing the degradation of $\mathrm{MB}$ on the $\mathrm{TiO}_{2}$ codoped with Co and Fe. Hence, this study provides a simple route to synthesize an effective photocatalyst for the degradation of dye compounds under visible light for wastewater treatment.

\section{Data Availability}

All the data used to support the findings of this study are included within the article.

\section{Conflicts of Interest}

There are no conflicts of interest to declare.

\section{Acknowledgments}

This study was funded by the Vietnam National Foundation for Science and Technology Development (NAFOSTED) under grant number 104.03-2019.313.

\section{References}

[1] D. Chen, Y. Cheng, N. Zhou et al., "Photocatalytic degradation of organic pollutants using $\mathrm{TiO}_{2}$-based photocatalysts: a review," Journal of Cleaner Production, vol. 268, p. 121725, 2020.

[2] M. Sun, Y. Fang, S. Sun, and Y. Wang, "Surface comodification of $\mathrm{TiO}_{2}$ with $\mathrm{N}$ doping and Ag loading for enhanced visible-light photoactivity," RSC Advances, vol. 6, no. 15, pp. 12272-12279, 2016.

[3] N. T. T. Mai, N. K. Nga, D. T. M. Hue et al., "Effect of calcination temperature on the structure and characteristics of 
cuprous oxide ( $\mathrm{Cu}_{2} \mathrm{O}$-ONPs)," in Proceedings of Second Annual Conference on Materials, Machine. Meth. for Sustainable Development (MMMS2020), pp. 375-383, 2021.

[4] Q. Sun, K. Li, S. Wu, B. Han, L. Sui, and L. Dong, "Remarkable improvement of TiO2for dye photocatalytic degradation by a facile post-treatment," New Journal of Chemistry, vol. 44, no. 5, pp. 1942-1952, 2020.

[5] M. K. Singh and M. S. Mehata, "Enhanced photoinduced catalytic activity of transition metal ions incorporated $\mathrm{TiO}_{2}$ nanoparticles for degradation of organic dye: absorption and photoluminescence spectroscopy," Optical Materials, vol. 109, p. 110309, 2020.

[6] M. A. Rauf, M. A. Meetani, and S. Hisaindee, "An overview on the photocatalytic degradation of azo dyes in the presence of $\mathrm{TiO}_{2}$ doped with selective transition metals," Desalination, vol. 276, no. 1-3, pp. 13-27, 2011.

[7] P. Jiang, W. Xiang, J. Kuang, W. Liu, and W. Cao, "Effect of cobalt doping on the electronic, optical and photocatalytic properties of $\mathrm{TiO}_{2}$," Solid State Sciences, vol. 46, pp. 27-32, 2015.

[8] J.-H. Shen, H.-Y. Chuang, Z.-W. Jiang, X.-Z. Liu, and J.J. Horng, "Novel quantification of formation trend and reaction efficiency of hydroxyl radicals for investigating photocatalytic mechanism of $\mathrm{Fe}$-doped $\mathrm{TiO}_{2}$ during $\mathrm{UV}$ and visible light-induced degradation of acid orange 7," Chemosphere, vol. 251, p. 126380, 2020.

[9] C. Gomez-Polo, S. Larumbe, A. Gila et al., "Improved photocatalytic and antibacterial performance of $\mathrm{Cr}$ doped $\mathrm{TiO}_{2}$ nanoparticles," Surfaces and Interfaces, vol. 22, p. 100867, 2021.

[10] A. Barmeh, M. R. Nilforoushan, and S. Otroj, "Wetting and photocatalytic properties of $\mathrm{Ni}$-doped $\mathrm{TiO}_{2}$ coating on glazed ceramic tiles under visible light," Thin Solid Films, vol. 666, pp. 137-142, 2018.

[11] T. Wang, D. Shena, T. Xua, and R. Jiang, "Photocatalytic degradation properties of $\mathrm{V}$-doped $\mathrm{TiO}_{2}$ to automobile exhaust," Science of the Total Environment, vol. 586, pp. 347-354, 2017.

[12] M. Sayed, A. Arooj, N. S. Shah et al., "Narrowing the band gap of $\mathrm{TiO}_{2}$ by co-doping with $\mathrm{Mn}^{2+}$ and $\mathrm{Co}^{2+}$ for efficient photocatalytic degradation of enoxacin and its additional peroxidase like activity: a mechanistic approach," Journal of Molecular Liquids, vol. 272, pp. 403-412, 2018.

[13] M. Shaban, A. M. Ahmed, N. Shehata, M. A. Betiha, and A. M. Rabie, "Ni-doped and $\mathrm{Ni} / \mathrm{Cr}$ co-doped $\mathrm{TiO}_{2}$ nanotubes for enhancement of photocatalytic degradation of methylene blue," Journal of Colloid and Interface Science, vol. 555, pp. 31-41, 2019.

[14] M. Imran, Z. Saeed, M. Pervaiz et al., "Enhanced visible light photocatalytic activity of $\mathrm{TiO}_{2}$ co-doped with $\mathrm{Fe}, \mathrm{Co}$, and $\mathrm{S}$ for degradation of Cango red," Spectrochimica Acta Part A: Molecular and Biomolecular Spectroscopy, vol. 255, p. 119644, 2021.

[15] A. Mancuso, O. Sacco, V. Vaiano et al., "Visible light active FePr co-doped $\mathrm{TiO}_{2}$ for water pollutants degradation," Catalysis Today, vol. 380, pp. 93-104, 2021.

[16] U. Holzwarth and N. Gibson, "The Scherrer equation versus the 'Debye-Scherrer equation'," Nature Nanotechnology, vol. 6, no. 9, p. 534, 2011.

[17] S. J. Gregg and K. S. W. Sing, Adsorption, Surface Area and Porosity, Academic Press, London, 2nd edition, 1982.
[18] E. D. Jeong, P. H. Borse, J. S. Jang et al., "Hydrothermal synthesis of $\mathrm{Cr}$ and $\mathrm{Fe}$ co-doped $\mathrm{TiO}_{2}$ nanoparticle photocatalyst," Journal of Ceramic Processing Research, vol. 9, pp. 250-253, 2008.

[19] Q. Wang, S. Xu, and F. Shen, "Preparation and characterization of $\mathrm{TiO}_{2}$ photocatalysts co-doped with iron (III) and lanthanum for the degradation of organic pollutants," Applied Surface Science, vol. 257, no. 17, pp. 7671-7677, 2011.

[20] M. A. Barakat, G. Hayes, and S. I. Shah, "Effect of cobalt doping on the phase transformation of $\mathrm{TiO}_{2}$ nanoparticles," Journal of Nanoscience \& Nanotechnology, vol. 5, no. 5, pp. 759765, 2005.

[21] T. Sun, J. Fan, E. Liu et al., "Fe and Ni co-doped $\mathrm{TiO}_{2}$ nanoparticles prepared by alcohol-thermal method: application in hydrogen evolution by water splitting under visible light irradiation," Powder Technology, vol. 228, pp. 210-218, 2012.

[22] S. Iyyapushpam, S. T. Nishanthi, and D. Pathinettam Padiyan, "Photocatalytic degradation of methyl orange using $\alpha-\mathrm{Bi}_{2} \mathrm{O}_{3}$ prepared without surfactant," Journal of Alloys and Compounds, vol. 563, pp. 104-107, 2013.

[23] G. Blanchard, M. Maunaye, and G. Martin, "Removal of heavy metals from waters by means of natural zeolites," Water Research, vol. 18, no. 12, pp. 1501-1507, 1984.

[24] Y. Wang, Y. He, T. Li, J. Cai, M. Luo, and L. Zhao, "Novel $\mathrm{CaBi}_{6} \mathrm{O}_{10}$ photocatalyst for methylene blue degradation under visible light irradiation," Catalysis Communication, vol. 18, pp. 161-164, 2012.

[25] R. Saravanan, S. Joicy, V. K. Gupta, V. Narayanan, and A. Stephen, "Visible light induced degradation of methylene blue using $\mathrm{CeO}_{2} / \mathrm{V}_{2} \mathrm{O}_{5}$ and $\mathrm{CeO}_{2} / \mathrm{CuO}$ catalysts," Materials Science and Engineering C, vol. 33, no. 8, pp. 4725-4731, 2013.

[26] R. Saravanan, H. Shankar, T. Prakash, V. Narayanan, and A. Stephen, " $\mathrm{ZnO} / \mathrm{CdO}$ composite nanorods for photocatalytic degradation of methylene blue under visible light," Materials Chemistry and Physics, vol. 125, no. 1-2, pp. 277-280, 2011.

[27] F. Jiang, T. Yan, H. Chen, A. Sun, C. Xu, and X. Wang, "A g$\mathrm{C}_{3} \mathrm{~N}_{4}$-CdS composite catalyst with high visible-light-driven catalytic activity and photostability for methylene blue degradation," Applied Surface Science, vol. 295, pp. 164-172, 2014.

[28] W. Yu, X. Liu, L. Pan et al., "Enhanced visible light photocatalytic degradation of methylene blue by F-doped $\mathrm{TiO}_{2}$," Applied Surface Science, vol. 319, pp. 107-112, 2014. 